\title{
Geochemical Occurrence of Rare Earth Elements in Mining Waste and Mine Water: A Review
}

\author{
Konstantina Pyrgaki ${ }^{1}{ }^{*}$, Vasiliki Gemeni ${ }^{1}$, Christos Karkalis ${ }^{1}$, Nikolaos Koukouzas ${ }^{1}$, Petros Koutsovitis ${ }^{2} \mathbb{D}$ \\ and Petros Petrounias 2 (D) \\ 1 Centre for Research \& Technology, Hellas (CERTH), 52 Egialias, Marousi, GR-15125 Athens, Greece; \\ gemeni@certh.gr (V.G.); karkalis@certh.gr (C.K.); koukouzas@certh.gr (N.K.) \\ 2 Department of Geology, Section of Earth Materials University of Patras, GR-26504 Patras, Greece; \\ pkoutsovitis@upatras.gr (P.K.); Geo.plan@outlook.com (P.P.) \\ * Correspondence: pyrgaki@certh.gr
}

check for updates

Citation: Pyrgaki, K.; Gemeni, V.; Karkalis, C.; Koukouzas, N.;

Koutsovitis, P.; Petrounias, P.

Geochemical Occurrence of Rare

Earth Elements in Mining Waste and Mine Water: A Review. Minerals 2021 11,860. https://doi.org/10.3390/ $\min 11080860$

Academic Editors: Gianni Gallello and Simon Chenery

Received: 15 July 2021

Accepted: 7 August 2021

Published: 10 August 2021

Publisher's Note: MDPI stays neutral with regard to jurisdictional claims in published maps and institutional affiliations.

Copyright: (c) 2021 by the authors. Licensee MDPI, Basel, Switzerland. This article is an open access article distributed under the terms and conditions of the Creative Commons Attribution (CC BY) license (https:/ / creativecommons.org/licenses/by/ $4.0 /)$.

\begin{abstract}
Mining waste, processing by-products and mine water discharges pose a serious threat to the environment as in many cases they contain high concentrations of toxic substances. However, they may also be valuable resources. The main target of the current review is the comparative study of the occurrence of rare earth elements (REE) in mining waste and mine water discharges produced from the exploitation of coal, bauxite, phosphate rock and other ore deposits. Coal combustion ashes, bauxite residue and phosphogypsum present high percentages of critical REEs (up to $41 \%$ of the total REE content) with $\Sigma$ REY content ranging from 77 to $1957.7 \mathrm{ppm}$. The total REE concentrations in mine discharges from different coal and ore mining areas around the globe are also characterised by a high range of concentrations from 0.25 to $9.8 \mathrm{ppm}$ and from 1.6 to $24.8 \mathrm{ppm}$, respectively. Acid mine discharges and their associated natural and treatment precipitates seem to be also promising sources of REE if their extraction is coupled with the simultaneous removal of toxic pollutants.
\end{abstract}

Keywords: rare earth elements; mining waste utilisation; acid mine drainage

\section{Introduction}

Rare earth elements (REE) are mainly divided into light and heavy rare earth elements (LREE and HREE, respectively). The LREEs are defined as the lanthanide elements from lanthanum through to samarium ( $\mathrm{La}, \mathrm{Ce}, \mathrm{Pr}, \mathrm{Nd}, \mathrm{Sm}$ ) and the HREEs as the lanthanide elements from europium through to lutetium and yttrium $(\mathrm{Eu}, \mathrm{Gd}, \mathrm{Tb}, \mathrm{Dy}, \mathrm{Ho}, \mathrm{Er}, \mathrm{Tm}, \mathrm{Yb}$, Lu \& Y). Yttrium is often grouped with the HREE due to its similar properties [1]. REEs are geochemically classified into three groups: the light rare earth elements (LREE- La, Ce, Pr, $\mathrm{Nd}$ and $\mathrm{Sm}$ ), middle rare earth elements (MREE: $\mathrm{Eu}, \mathrm{Gd}, \mathrm{Tb}$, Dy and $\mathrm{Y}$ ) and heavy rare earth elements (HREE: Ho, Er, Tm, Yb, Lu) [2,3].

The extended use of REEs is linked to their magnetic, catalytic and optical properties. Their main uses are in the automotive, telecom and electronic sectors, as well as aerospace, defence, and renewable energy. Their demand in recent years has continued to increase with the global production of REEs reaching 190,000 and 210,000 tonnes in 2018 and 2019, respectively (USGS, 2020). Between now and 2026, growth in demand will be linked to the production of $\mathrm{NdFeB}$ magnets for hybrid and electric vehicles, and wind turbines [4].

Currently, the world reserves of REE are mainly located in China, Brazil, Vietnam, Russia and India. China, with nearly half of the world's known REE reserves, still dominates REEs production, contributing to approximately $63 \%$ of the global production [5]. REEs are commercially extracted from rare earth deposits that contain REEs-bearing minerals such as bastnaesite, monazite, loparite, xenotime and REE rich clays. REEs ore deposits occur in a wide variety of rocks and genetic types [6]. The most important ones for commercial exploitation are carbonatite-associated deposits, ion adsorption deposits, alkaline igneous rocks placer deposits, more anecdotic hydrothermal deposits and seafloor deposits. The 
primary resources of REEs have been identified and explored during the last decades in many areas in Europe such as Sweden, Norway, Greenland and Turkey [1]. However, none have so far been manufactured. Instead, secondary sources of REE, mainly from the recycling or processing of waste materials, are drawing the attention of both the scientific community and the industry, as they can become a new source of supply $[7,8]$.

The recovery of REEs by recycling secondary resources can diminish the environmental footprint as well as the costs involved in mining and processing primary ores [9]. Many secondary sources of REEs appear promising, such as: mining waste produced during mining and metallurgical activities such as acid mine drainage (AMD), bauxite residue (BR), coal combustion products (CCP) and other ore mining waste such as tailings and sludge [10-13]. The major difficulty regarding the exploitation of mining waste is the high degree of heterogeneity (waste quantities, metal content and distribution, mineralogy, etc.) causing several limitations for the upscaling of promising recovery technologies [14]. As a result, it is an urgent challenge to better understand the mineralogy and geochemical characteristics of REE secondary sources to find more efficient recovery methods targeting the zero-waste concept. Within such a framework, the overall scope of the current review paper is the comparative study of the geochemical occurrence of rare earth elements (REE) in mining waste and mine water discharges produced from coal, bauxite phosphate rock and other ore mining activities. In particular, the main objectives are (1) to discuss the geochemical occurrence of REE in different types of mining waste and (2) to identify the geochemical processes which are involved in the enrichment of REE in the mining waste of different mine types. To the best of our knowledge, this is the first literature review which focuses on the geochemical occurrence of REEs in mining waste, whereas the majority of the published reviews mainly focus on recovery technologies. This information will improve the knowledge of current research, highlighting the challenges involved in the recovery of REEs.

\section{Materials and Methods}

A compilation and analysis of data from several studies, that have investigated the occurrence of REE in different types of mining waste, was performed. Google Scholar was used as the search engine to find the relevant publications. Based on the review objectives the following keywords were considered in different combinations: mining waste, REE, rare earth elements, coal fly ash, coal ash, coal combustion by-products, bauxite residue, red mud, mine water, acid mine drainage, mine tailings, ore mining waste, geochemical occurrence, phosphate waste, and phosphogypsum. Using the logical operators available in the Google Scholar search engine, we set a query so as to search through the records and reach the publications that included at least one of these keywords in each tier in their title, abstract, or list of keywords. We focused on the literature of the last ten years by identifying articles with supplementary material that included raw data for the metadata analysis. A total of 154 papers were finally selected and evaluated by the authors to assess their relevance for the review objectives. After review papers and non-English papers were removed, 142 papers remained. In the end, a total of 135 publications were selected to be included in the review. The publications excluded at the last stage were related to recovery technologies of REEs without mentioning the relevant data for the scope of the present review.

These data were also supplemented by the REY composition of ten fly ash samples collected from five power plants in Greece. These included the power plants of Amyntaio, Agios Dimitrios, Kardia, Meliti (northwestern Greece) and Meagolopoli (southern Greece). The chemical analyses were performed at the ACME Analytical Laboratories in Canada with the use of ICP-MS. Detection limits ranged between 0.01 and $0.05 \mathrm{ppm}$ for rare earth elements and between 0.1 and $10 \mathrm{ppm}$ for yttrium. The compiled data were used to build a consistent database of REE concentrations to examine possible trends in REE abundance among the different types of mining waste (Tables S1 and S2). The database was developed in order to contain a representative number of samples for each type of mining waste, 
whilst maintaining the scope to complement the literature review process. In the respective database, the reported REE concentrations included the 14 naturally abundant lanthanides and $Y$ when the respective measurements were available.

In total, 543 samples comprising of both solid material and mine water were included in the database. Specifically, 302 samples were compiled in the database for coal mining waste (coal ash, fly ash, coal waste and coal mine drainage). To better understand the relative REE abundance among the different types of coal mining waste for each coal basin, the compiled data were classified into three sub-types: (a) fly ash collected from electrostatic precipitators (EPS), (b) other coal ash (bottom ash collected from the power plants or coal ash generated in the laboratory), and (c) coal waste which may correspond to a mixed material of landfilled ash and/or coal refuse/gangue material. It must be mentioned that the term 'coal ash' in this study was used only for the aforementioned ashes and it did not include the fly ashes which were classified separately. In the case of coal mine drainage, a total of 84 samples were included. For bauxite residue (red mud), a total of 18 samples were acquired originating from different bauxite deposits around the globe. For phosphate waste a total of 8 samples including tailings, waste clay and phosphogypsum (PG) were also included in the database. Regarding the mining waste from other ore deposits, 72 samples from mine tailings and associated landfilled material were included as well as 53 samples of non-treated acid mine discharges. In this case, Y concentrations were not available for all the samples so the respective diagrams were plotted without Y. The REE concentrations of the solid samples of the dataset were normalised to upper continental crust values (UCC) [15] to allow for comparison with the REE distribution among the different types of mining waste.

Finally, to assess the potential of the solid mining wastes as secondary sources of REEs, the total rare earth oxide (REO) content had to be greater than $1000 \mathrm{ppm}(0.1 \% w / w)$ [3]. For this reason, only the samples which met the above criterion were included in the respective calculations. The ratio of the relative amount of critical REEs in the REE sum to the relative amount of more abundant REEs was proposed for a primary assessment of ore quality. The following ratio is the outlook coefficient [3]:

$$
\text { Coutl }=(\mathrm{Nd}+\mathrm{Eu}+\mathrm{Tb}+\mathrm{Dy}+\mathrm{Er}+\mathrm{Y} / \Sigma \mathrm{REY}) /(\mathrm{Ce}+\mathrm{Ho}+\mathrm{Tm}+\mathrm{Yb}+\mathrm{Lu} / \Sigma \mathrm{REY})
$$

The higher the coefficient is, the more promising the REY ore, with respect to potential industrial value.

\section{Geochemical Occurrence of REE in Coal Mining Waste}

\subsection{Coal Mining and Combustion by-Products}

REY-rich coals are formed under various geological conditions, at different stages during the evolution of coal basins, through various ore forming processes $[3,16]$. The following four genetic types of REY accumulation in coal are identified [3]: (a) the terrigenous type, with REY input by the surface waters; (b) the tuffaceous type, connected with falling and leaching of acid and alkaline volcanic ash; (c) the infiltrational or meteoric groundwater-driven type and (d) the hydrothermal type, connected with the circulation of deep hydrothermal fluids [17]. The influence of hydrothermal solutions leads to sulphur and REY enrichment of the primary coal in the Rasa coal basin, Croatia [18]. The REY in coals are hosted within fine-grained authigenic minerals (REY-bearing aluminum phosphates and sulphates of the alunite group, and water-bearing phosphates and carbonates) and organic compounds. Bastnäsite $\left[(\mathrm{La}, \mathrm{Ce}, \mathrm{Y}) \mathrm{CO}_{3} \mathrm{~F}\right]$ is one of the major REE carbonate hosts, in the late Permian coals from the Moxinpo coalfield, in southwestern China [19]. Phosphate minerals such as xenotime, Gd-apatite and Y-crandallite are also important REY-carriers [20]. Extensive literature data indicate that the distribution of REE in coal combustion by-products depends mainly on the chemical composition of the primary source coal, since REE do not show a volatile behaviour [3,21].

The concentration of REE exhibits a significant range among the different regions of exploitation (Figures 1a,b and 2). In this context, REE concentrations in the coal ashes 
from the different coal basins range from $77 \mathrm{ppm}$ in the Binxian coalfield in China [22] to 1175 ppm in the Appalachian coal basin in USA [23] (Figure 1a). The highest median of REE concentrations belongs to the coal ash of the Appalachian basin (529 ppm), followed by the Illinois coal basin with $290.6 \mathrm{ppm}$, the Binxian coal basin with $211 \mathrm{ppm}$ and the Northwest Thrace coal basin with $194.7 \mathrm{ppm}$. Coal ashes from the Illinois basin (USA) present sub-parallel and relatively flat upper continental crust-normalised REE-patterns (UCCN) compared to those of the Powder River basin (USA). Both regions are characterised by remarkable positive Eu anomalies $\left(\mathrm{Eu}^{*} / \mathrm{Eu}_{\mathrm{UCCN}}=0.24-0.26\right.$ and $0.24-0.33$ for the Illinois and Powder coal basins, respectively). The presence of plagioclase crystals usually justifies the positive Eu anomalies [24-26]. This is further confirmed by the fact that the rocks of the Powder basin are usually plagioclase-rich.
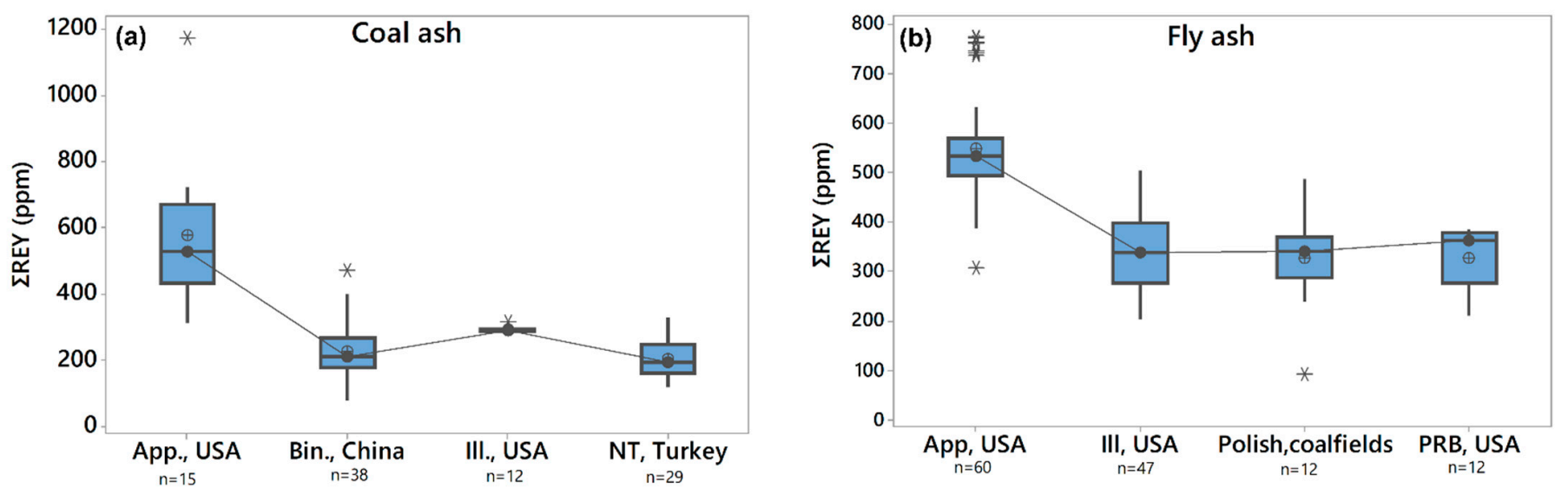

Figure 1. (a,b) Boxplots of RE $\Upsilon$ concentrations for coal ash and fly ash, respectively, from different coal basins: Appalachian (App. USA), Illinois (Ill. USA), Powder river coal basin, USA [23], Binxian (Bin., China) [22], Northwest Thrace coal basin (NT, Turkey) [27], Polish coalfields [13] (*: outlier values).

The Appalachian coal ash samples exhibit a wide range of REE contents, whereas their upper continental crust (UCC)-normalised REE-patterns occur in cases characterised by either negative or positive anomalies $\left(\mathrm{EU}_{\mathrm{UCCN}}=0.56-1.05\right)$. The enrichment of the Appalachian basin coal ashes tends to be greater in MREEs and HREEs, especially Gd (that often exhibits positive anomalies) and Dy, relative to the LREEs (Figure 2a). Regarding the coal ashes from China, those of the Binxian region exhibit a slight fractionation between LREE and HREE, marked by high LREE contents [22], whereas, in some cases, Gd presents positive anomalies. The upper continental crust (UCC)-normalised REE-patterns of the Hancheng coal ashes (China) are quite flat and show slight negative Ce and significant positive Gd anomalies. In the Northwest Thrace coal basin, coal ashes generated in the laboratory show fractionation between HREE and LREE, characterised by HREEenrichments, except for Eu and Gd, which are depleted [27] and present remarkable positive $Y$ anomalies. The coal ash from the Raša coal deposit in Croatia has a maximum REO content of $464 \mathrm{ppm}$. Among the different coalfields, the enrichment factors of the individual REEs vary [18].

Many researchers have identified coal fly ash as a resource of REE [2,28]. The REE concentrations in fly ashes from the different coal basins range from $91.8 \mathrm{ppm}$ in the Polish coalfields [13] to $775.5 \mathrm{ppm}$ in the Appalachian coal basin, USA ([23]; Figure 1b). Fly ash from the Appalachian coal basin (Figure 2b) has the highest median value of REE concentration (532.1 ppm) whereas the Illinois, Polish coalfields and the Powder River coal basin present similar median values, $338.9 \mathrm{ppm}, 348.1$ and $361.9 \mathrm{ppm}$, respectively. The fly ashes originating from the Powder River coal basin exhibit significant enrichment regarding the MREE and especially Eu, which has the highest median value of 4.0. Polish coalfield fly ashes also present higher enrichment factors in medium REE [23]. 

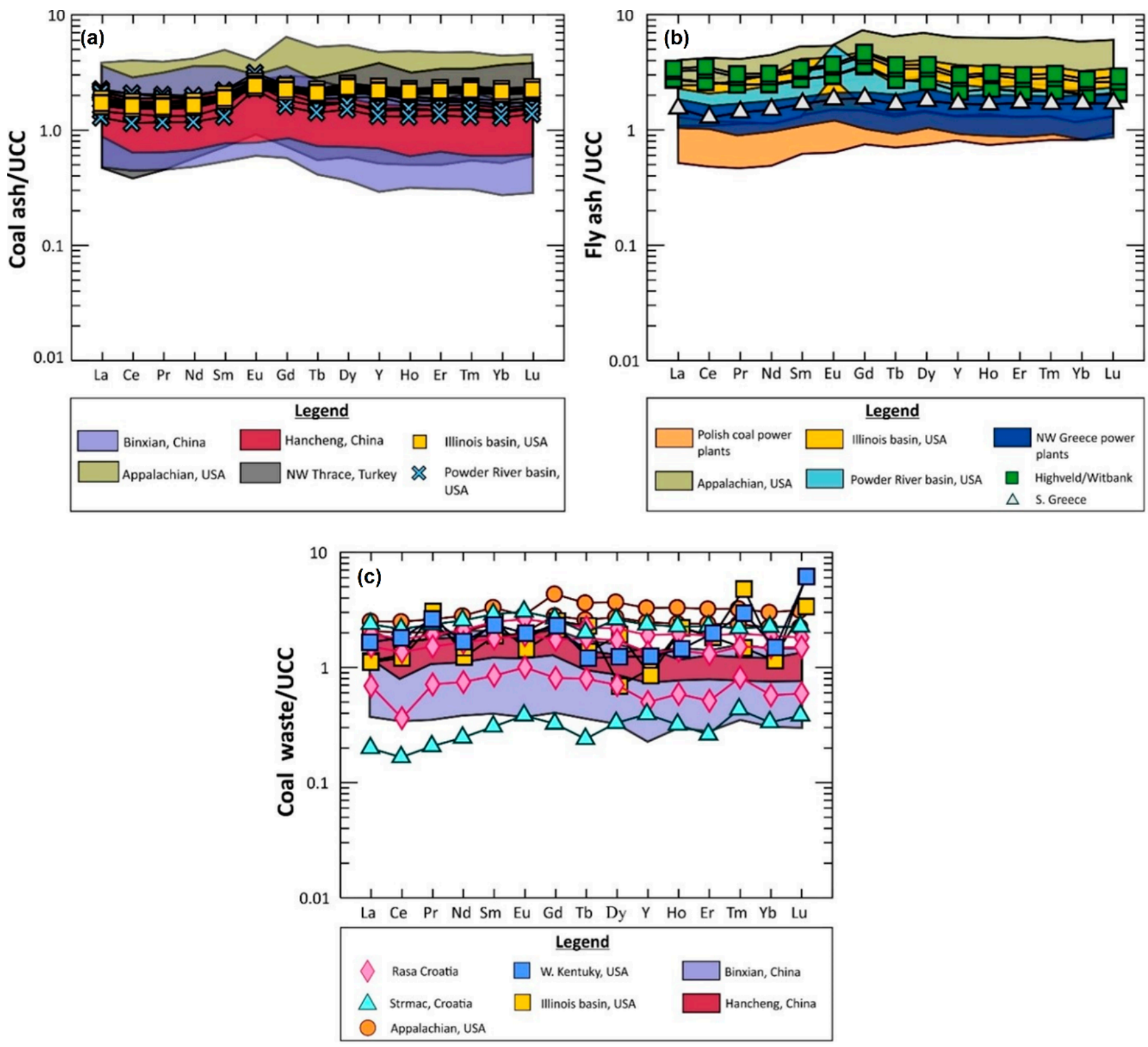

Figure 2. Upper Continental Crust (UCC) normalised-REE patterns of: (a) coal ash [22,23,27], (b) fly ash [13,23], (c) coal waste $[18,22,23,29]$. Normalisation factors after Taylor and McLennan [15].

Pan et al. [30] studied fly ashes from Nayong power plant in China and found that REY concentrations were enriched with increasing particle size. They also reported that REY occurrence was mainly associated with silicate and aluminosilicate fractions $(65.22 \%)$, while a lower percentage $(12.12 \%)$ belonged to an organic or sulphide fraction, concluding that REY in the coal fly ash (CFA) was significantly associated with $\mathrm{Al}$ and P. This indirectly indicates the existence of REY-bearing aluminum phosphates and sulphates of the alunite supergroup (APS minerals) and REY-bearing organic compounds (humic matter) in the primary coal. In fly ashes originating from the USA coal basins (Appalachian, Illinois and Powder river basins) REEs occur in the aluminosilicate glass with $\mathrm{Ca}$, Fe-enriched aluminosilicate glasses to present higher REE contents than pure Al-Si glasses [28]. Taggart et al. [23] also found that fly ashes from the different coal basins in the USA were correlated positively with $\mathrm{Al}$, indicating that the main REE bearing phases were aluminosilicate glasses. Liu et al. [31] identified a range of REE phases in fly ashes from USA coal basins such as REE oxides, REE phosphates, apatite, zircon, and REE-bearing glass phases. In addition, in fly ash and bottom ash samples from the National Energy Technology Laboratory, USA REE-bearing 
phosphate minerals (rhabdophane, monazite, xenotime, and apatite) occur as ashes and crystals in the rock pore space [32,33]. According to Franus et al. [13] Polish coal fly ashes also exhibited a correlation between REE, $\mathrm{Al}$ and $\mathrm{Si}$ indicating that the main REEs hosts were aluminosilicate glasses. Concerning the bottom ash deposit at Ceplea Valley, Romania, the SEM/EDS results showed that the only REE-bearing minerals are micrometer-sized phosphate grains with $\mathrm{Ce}$, $\mathrm{La}$ and $\mathrm{Nd}$, with an average diameter of $4.85 \mu \mathrm{m}$, which must be dispersed in the glassy aluminosilicate matrix [13,34]. Greek fly ashes were studied from selected sampling sites of northwestern and southern Greece. In both cases they exhibited relatively flat upper continental crust (UCC) -normalised REE patterns. Fly ashes of northwestern Greece occasionally showed slight positive Dy and Eu anomalies $\left(\mathrm{Eu}^{*} / \mathrm{Eu}_{\mathrm{UCCN}}=0.97-1.13\right)$ and sub-parallel patterns with those of the Illinois basin. Their $\Sigma$ REE content including Y ranged between 172.78 and $279.87 \mathrm{ppm}$. In particular, Greek fly ashes were substantially enriched in LREE $(\Sigma$ LREE $=128.55-201.82 \mathrm{ppm})$, whereas in MREE and HREE were less abundant (14.30-26.25 ppm and 5.42-11.40 ppm for MREE and HREE, respectively). The positive correlation of LREE with Th (not shown here) was highly indicative of the presence of monazite, which is regarded as major Th-LREE source. This scenario was further enhanced by the fact that $\mathrm{La}$ and $\mathrm{Ce}(\mathrm{La}+\mathrm{Ce}=95.50-147.30 \mathrm{ppm})$ were observed in higher amounts compared to those of $\mathrm{Pr}$ and $\mathrm{Nd}(\mathrm{Pr}+\mathrm{Nd}=33.05-54.52 \mathrm{ppm})$.

It is well established that the morphology of a fly ash particle is controlled by the combustion temperature, and that the combustion process results in an enrichment of metal concentrations in the coal ash, often four to ten times larger, in relation to coal [13]. Additionally, even though coal is subjected to many transformations during and after combustion (e.g., decomposition, volatilisation, fusion, agglomeration or condensation), according to the aforementioned studies it seems that the aluminosilicate fraction of fly ash is the most enriched in REE regardless of the origin of primary coal. This shows that the combustion process does not have a great impact on the REE-bearing minerals. Nevertheless, it cannot be dismissed that calcination could result in thermal decomposition of minerals and the re-distribution of individual REE among the different mineralogical fractions, such as the oxidation of sulphide minerals into low-solubility oxides (e.g., hematite) [35]. It must be mentioned that in synthetic-representative REE-bearing phases, during heating up to $1500{ }^{\circ} \mathrm{C}$, REE-lignin and REE-chitosan complexes, hydrated $\mathrm{Y}_{2}\left(\mathrm{CO}_{3}\right)_{3}$ and $\mathrm{Ce}_{2}\left(\mathrm{CO}_{3}\right)_{3}$, bastnäsite, and REE-doped calcite, transform into corresponding oxides after heating, accompanied by $\mathrm{Ce}$ (III) oxidation, whereas apatite, monazite, xenotime, and zircon are barely altered [31]. On the contrary, the total REE content and the enrichment of the individual rare earth elements in both coal and fly ash varies among different coal deposits, due to the different genetic type of the primary coal.

REE concentrations in coal dumps from the Binxian coalfield and the Hancheng coalfield in China (Figure 2c) range from 59.9 to $301.9 \mathrm{ppm}$ with its median values measuring 175.7 and 215 ppm, respectively [22]. Their upper continental crust (UCC)-normalised patterns exhibit a slight fractionation between LREE and HREE, occasionally characterised by negative $\mathrm{Ce}$ and $\mathrm{Y}$ anomalies, as well as slightly positive $\mathrm{Gd}$ anomalies. The last are attributed to the interaction with hydrothermal fluids, which are derived from middleocean ridge settings [22,36,37]. Honaker et al. [29] found that the REE content in coal refuse samples from the West Kentucky and Illinois coal basins ranged from 32 to $180 \mathrm{ppm}$. Wen et al., [38] reported that REE concentrations in coal gangues from Xishan coalfield in China ranged from 96.65 to $379 \mathrm{ppm}$ and suggested that REE would occur mainly in clay minerals such as kaolinite, whereas the presence of apatite could further explain the observed REE-enrichments. The coal gangues were covered by sedimentary formations, indicating that the most common source of REE is terrigenous debris [38]. The coal waste piles from the Nowy Wirek coal mine, Poland were enriched in REE elements with its concentrations ranging from 83.25 to $355 \mathrm{ppm}$. Honaker et al. concluded that the main REE bearing minerals were clay minerals [39]. In this context, the observed abundance in REE was highly affected by the thermal alteration degree, coupled with the burning degree of organic matter and clay mineral-dehydroxylation [39]. According to Zhang et al. [40], 
middling and coarse refuse samples from Beckley plant, USA had a REE content of 198 and 283 ppm, respectively, with both the LREEs and HREEs existing as phosphate minerals. In general, coal dumps were characterised by lower concentrations of REE comparatively with coal ash and fly ash.

Interpretation of the distribution of REEs among the different types of coal mining by-products (coal wastes, coal ash and fly ash), in terms of geological and physicochemical processes, is a complex procedure that must take into consideration several parameters. In particular, the observed REEs enrichments and depletions are controlled by the mineralogical composition of the coal, the petrological classification and mineralogical composition of the surrounding rocks and sediments, as well as by variable geological processes such as interaction with hydrothermal fluids and/or meteoric/surface waters.

In this context, the observed REE-enrichments in several Chinese (Binxian and Hancheng) coal by-products plausibly resulted from their interaction with hydrothermal derived fluids, which are associated with the adjacent ultramafic, mafic, intermediate and felsic rocks [22,41]. This is further confirmed by the fact that the REE-enriched coal ash samples from the Hancheng locality also exhibited positive Eu anomalies, which were attributed to the involvement of hydrothermal and high-temperature fluids [22].

The Illinois and Powder basin coal ashes show similar REE contents compared to those of the Chinese samples, which suggests that they may have been subjected to similar geochemical processes. The highest REE contents, which are observed in the coal waste and coal ash samples of the Appalachian basin are linked with the higher organic contents in coal, coupled with the effect of feeding solutions that penetrated the coal during the early stages of their formation [32]. The lower REEs content, which is observed among the different types of coal mining by-products can be assigned to the effect of leaching processes via underground waters [32]. The development of redox reactions can be linked with depletions in significant REEs, such as $\mathrm{Ce}$, causing subsequent negative anomalies [22], whereas the further establishment of REE depletions can be assigned to the interaction of the initial coal seam with seawater [22]. These could also justify the observed differences on the REE contents between the studied coal by-products among the different studied regions.

The aforementioned findings indicate that the interaction of coal with REE-bearing hydrothermal and/or meteoric fluids are two of the most common processes that geochemically control the observed REE enrichments. On the other hand, the predominance of redox conditions and/or the involvement of leachate solutions are substantially associated with REE depletions.

\subsection{Coal Mine Water Discharges}

REEs in coal mine drainage samples collected from different coal basins around the globe are characterised by a high range of concentrations varying from 0.3 to $9879 \mathrm{ppb}$ (Figure 3a). REEs concentrations can also greatly vary within the same coal basin (Figure 3a). This is attributed to the different geochemical processes occurring in different areas of the same coal basin.

The neutral mine drainage in the vicinity of the Anjir Tangeh coal-washing plant in Iran shows heavy REE (HREE)-enrichment with REE concentrations ranging from below the limit of detection to $15.1 \mathrm{ppb}$ [42]. In addition, REEs are proven to be associated with aluminium phosphate minerals, as REEs are positively correlated with $\mathrm{Al}, \mathrm{P}, \mathrm{La}, \mathrm{Gd}, \mathrm{Sm}$, $\mathrm{Pr}, \mathrm{Nd}, \mathrm{Ce}, \mathrm{Dy}$ and $\mathrm{Y}$, indicating that the aforementioned minerals are the main source [42]. The acid mine drainage (AMD) originating from the Xingren coalfield, China, shows a slight enrichment in MREEs ( $\Sigma$ REE ranged from 118 to $926 \mathrm{ppb}$ ) whereas their parent rocks are more enriched in LREEs and MREEs [43]. Lefticariu et al. [44] reported that the $\Sigma$ REEs in coal mine drainage (CMD) from the Illinois coal basin, varied between 1 and $9879 \mathrm{ppb}$, concluding that the aluminosilicate minerals and especially Al-rich clay minerals (i.e., kaolinite, illite) were the main sources of REEs in CMD. Vass et al. [11] found that REE concentrations in CMD of the Northern Appalachian coal basin ranged from 0.25 to $3100 \mathrm{ppb}$ with HREE becoming more enriched, suggesting that REE occurrence in the 
host strata was associated with manganese oxides and aluminosilicates. Possible sources of REEs in CMD of the Appalachian coal basin, are phosphate and carbonate minerals, occurring in the carbonate cement of shales or sandstones [45]. Based on the literature review and the North American Shale and NASC-normalised patterns of REE content in CMD provided by Worall and Pearson [46], middle REE enrichment has been commonly reported. Stewart et al. [47] have also reported that CMDs from the Appalachian coal basin are mainly enriched in MREE, with $\Sigma$ REY concentrations ranging from 0.29 to $1134 \mathrm{ppb}$. Nevertheless, the MREE enrichment in coal mine drainage does not reflect the chemical composition of bulk rock units with which the CMD has interacted [47]. This indicates that REEs in CMD are largely determined by the physicochemical conditions that prevail in the aqueous phase during water rock interaction.
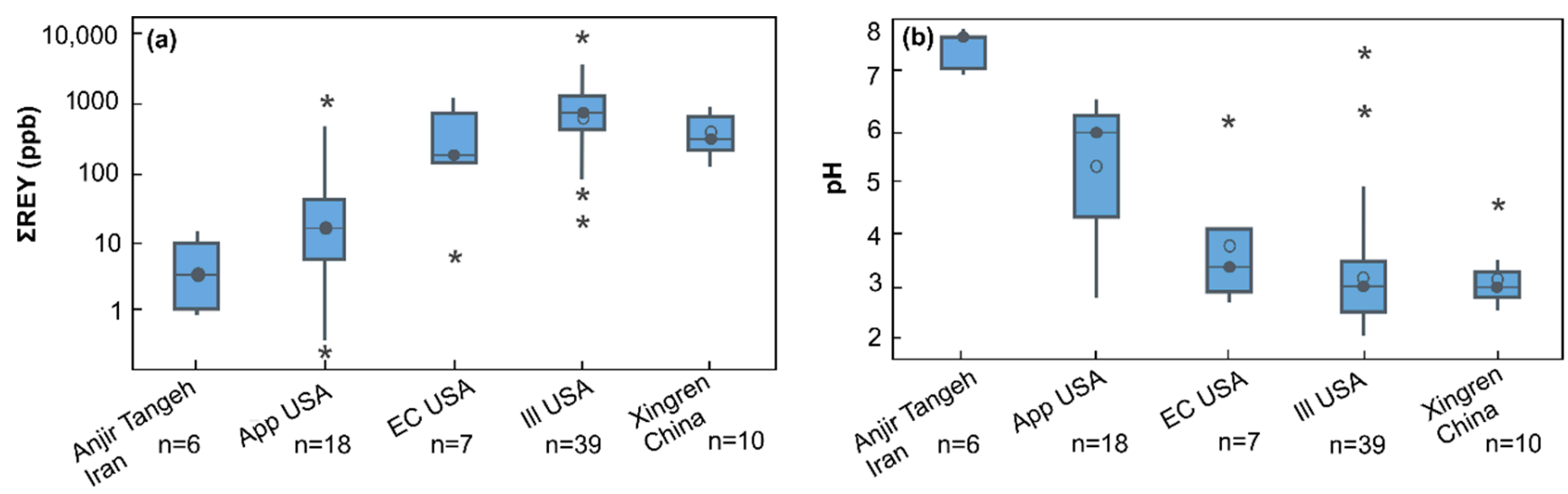

Figure 3. Boxplots of (a) $\Sigma R E Y$ concentrations and (b) $\mathrm{pH}$ values for coal mine drainage from different coal mines [42-44,47,48], (*: outlier values).

The $\mathrm{pH}$ of CMD is a significant parameter controlling both the REEs release from the associated minerals as well as the speciation of REEs in the aqueous phase. As it is shown in Figure $3 b$, total REE concentrations in CMD increase as the $\mathrm{pH}$ decreases among the different coal basins. This general trend has been observed by several studies [11,45]. As $\mathrm{CMD} \mathrm{pH}$ increases, REEs decrease due to the adsorption and co-precipitation of $\mathrm{Al}$ and Fe hydroxides [42]. Data from the Appalachian coal mine [47] indicate that at a $\mathrm{pH} \geq 6.6$ the $\Sigma$ REE content in the CMD drops significantly, showing the possible adsorption of co-precipitation with aluminium or ferric iron into a solid phase prior to discharge. For this reason, in CMDs characterised by neutral to alkaline $\mathrm{pH}$, REEs concentrations are significantly decreased comparatively with more acidic CMD (Figure 2a,b). At slightly alkaline $\mathrm{pH}$ values the main REE species are carbonate $\left(\mathrm{Ln}\left(\mathrm{CO}_{3}\right)^{2-}\right)$ and $\left(\mathrm{Ln}\left(\mathrm{CO}_{3}\right)^{+}\right)$complexes [42], whereas at acidic $\mathrm{pH}$ values sulphate complexes $\left(\mathrm{Ln}\left(\mathrm{SO}_{4}\right)^{+}\right.$and $\left.\mathrm{Ln}\left(\mathrm{SO}_{4}\right)^{2-}\right)$ are the dominant compounds [43,44]. Another reason why REE concentrations are higher in AMD than in neutral mine drainages is because the acidic conditions favour the dissolution of minerals in tailings and bedrocks, thus releasing higher dissolved concentrations of REEs into the waters. In AMD, the MREE are more enriched, compared to LREE, in elements such as $\mathrm{La}$ and $\mathrm{Ce}$, as these elements are often associated with phosphate minerals (e.g., monazite) which are more resistant to dissolution [11]. This also indicates that the geochemical processes (e.g., acidic dissolution, precipitation, sorption, and dilution) that control AMD formation also control REE leaching and occurrence in the AMD discharges.

The place of discharge point within the coal mine is also an important parameter for REE occurrence in CMD. REE concentrations increase gradually downstream of the discharging point of the plant reject water [42]. Nevertheless, Kefeni et al. [49], reported that REEs concentrations decrease significantly as the distance from the discharging point increases. The elevation of the discharge point (above or below the mine drainage system) has a clear impact on REE concentrations in CMD, with lower concentrations occurring in the below-drainage flooded mine complexes [11]. Precipitates from coal AMD treatment 
can also be considered as feedstock for REE production. Precipitates from the Appalachian coal basin contain an average concentration of 724 ppm of REEs, estimating that the total REE flux passing through AMD treatment systems is 13,000 kg/year [11]. The Al and Mn-rich treatment solids from the passive treatment systems of CMD from eastern U.S. coalfields are enriched in MREE and HREE, relative to the North American Shale Composite, with up to 1950 ppm REE [48]. Nevertheless, the REE content of the precipitate depends not only on the concentrations of REE in the particular CMD outflow that is being treated, but also on other factors such as water chemistry, solid-liquid partition coefficients and treatment methods. The passive treatment of low-pH CMD with the addition of limestone produces precipitates with a higher REE content comparatively with active systems where lime is used [48]. This is because, in active treatment systems, lime addition results in non-targeted precipitation (e.g., calcite, gypsum, and $\left.\mathrm{Mg}(\mathrm{OH})_{2}\right)$ ) diluting the REE concentrations in the final precipitate. The precipitates from the Appalachian coal basin can be classified into three groups based on their chemical composition [47]: (a) Ca and $\mathrm{Mg}$-rich, (b) Si and $\mathrm{Al}$ rich and (c) Fe-oxy-hydroxide precipitates showing that $\mathrm{Si}-\mathrm{Al}$ precipitates have the greatest enrichment. The precipitates exhibited an MREE enrichment similar to that of the CMD raw discharge but at significantly higher concentrations [47].

In conclusion, the great variation of REE concentration levels (from 0.3 to $9879 \mathrm{ppb}$ ) from area to area was mainly due to the different geochemical and physicochemical conditions that prevailed in each area. In particular, the most important factor was the $\mathrm{pH}$ of the coal mine drainage, while the mineralogy of the REEs in the source rocks (for example phosphates, oxides or clay minerals) and the elevation of the CMD discharge point (above or below to mine drainage system) were also significant. In general, REE concentrations levels increased as the $\mathrm{pH}$ decreased as the precipitation of $\mathrm{Al}$ and $\mathrm{Fe}$ hydroxides was not favoured.

\section{Geochemical Occurrence of REEs in Bauxite Residue (Red Mud)}

Red mud is produced by the extraction of alumina from bauxite ores with the Bayer process [50]. In the source rock-bauxite, the most common authigenic REE bearing mineral is $\mathrm{Nd}$-hydroxylbastnäsite $\left[\mathrm{Nd}\left(\mathrm{CO}_{3}\right)(\mathrm{OH})\right]$, whereas monazite, $\left[(\mathrm{Ce}, \mathrm{La}, \mathrm{Nd}, \mathrm{Th}) \mathrm{PO}_{4}\right]$ is the most common detrital REE-bearing mineral [12,51,52]. The bulk mineralogical composition of red mud includes aluminium oxide phases (boehmite, diaspore), ferrous minerals (hematite, goethite, and limonite), rutile, anatase, pyrite, calcite, and dolomite. The new phases formed during the Bayer process are mainly sodalite and gibbsite [8,53]. During the Bayer process, the bulk REE component is almost entirely transferred into bauxite residue $[54,55]$. In the last few years, several researchers have investigated the exploitation of red mud as a secondary source for the recovery of REEs such as La, Y and Sc $[51,53,55]$.

Red muds from the lateritic-type Timan bauxites in Russia have been shown to contain up to $90 \%$ of the $\mathrm{Nb}$, Sc and REEs present in the original bauxite [56]. In the same context, Ochsenkühn-Petropoulou et al. [57], as well as Wagh and Pinnock [58] have demonstrated two-fold increases in REE, including Sc and Y, in red muds when compared to the bulk chemistry of the Greek- and Jamaican-source bauxites, respectively [51]. This proves that the enrichment of red muds in REE depends on the source ore proving, thus proving the aforementioned assertion related to the content of REE in the red mud. Therefore, the European refineries that import bauxite from a wide range of sources have great difficulty in estimating the average REE content in the red mud [51].

Red mud contains a minor fraction of REE ranging from 137.2 to $1957.7 \mathrm{ppm}$ (Table S1). It is interesting to note that the $\mathrm{Sc}$ fraction is quite significant, ranging between 130 and 390 ppm [59]. Scandium (Sc) may represent 95\% of the economic value of REE in red mud $[60,61]$ and is considerably enriched in the bauxite residue compared to the original ore [62]. In Jamaican bauxite, the Sc concentration ranges from 87 to $113 \mathrm{ppm}$ as $\mathrm{Sc}_{2} \mathrm{O}_{3}$ and is accumulated and enriched to levels as high as 200-390 ppm in the red mud. The same applies for the other REEs in the Jamaican red mud, which exhibit almost double concentration in relation to their respective bauxite ores [58]. The red mud generated in 
Greece has a high, uniform content of about $130 \mathrm{ppm}$ of Sc in the dry red mud, corresponding to $0.02 \%$ of $\mathrm{Sc}_{2} \mathrm{O}_{3}$, which is considered a valuable scandium resource. Sc extraction can be accomplished either through hydrometallurgical treatment or a combination of pyro-hydrometallurgical treatment processes $[54,55,61]$, while the selective leaching and extraction of REEs (including Sc) is based on variable substances such as carbonates [63], sulfurous acids [64], sulfuric acid, hydrochloric and nitric acid [61,65]. In general, the recoverability of Sc ranges between $20 \%$ and $50 \%$, whereas the other REEs exhibit a recovery rate of $80 \%$ [61]. In the case of Greek bauxite residues, leaching with the Ionic liquid HbetTf2 $\mathrm{N}$ (38) could result in increasing the recoverability of REEs and Sc values reaching up to $140 \mathrm{mg} / \mathrm{L}$ and $45 \mathrm{mg} / \mathrm{L}$ respectively [61]. In the same context, the Sc extraction from Jamaican red mud can be implemented in an economically feasible and non-hazardous manner [58]. Recoverability of Sc in these red muds has been studied by Narayanan et al., 2016 [66]. Their method provides 75\% recovery of Sc by increasing the leach-liquor $\mathrm{pH}$ with $\mathrm{NaOH}$ addition, avoiding the use of organic extractants and solvents, due to their high cost [66].

In addition, red mud can be enriched comparatively with the upper continental crust in almost all the REEs (Figure 4). It is observed that the majority of bauxite residues are characterised by a positive Ce anomaly whereas some others such as Turkish and Jamaican are more enriched in $\mathrm{Tb}$ and Tm relatively, with upper continental crust (UCC). Laboratory research results indicate that the most abundant REE-bearing phases are LREEferrotitanates with major compositions ( $\mathrm{REE}, \mathrm{Ca}, \mathrm{Na})(\mathrm{Ti}, \mathrm{Fe}) \mathrm{O}_{3}$ and $(\mathrm{Ca}, \mathrm{Na})(\mathrm{Ti}, \mathrm{Fe}) \mathrm{O}_{3}$ [53]. These are secondary phases formed during the Bayer process by an in situ transformation of the precursor bauxite, whereas heavy REEs occur in the same form as in bauxites, namely as Y phosphates. Similar results are reported by Gamaletsos et al. [67] who concluded that Ce presence might be related to the occurrence of a loparite type phase (belonging to perovskite group).

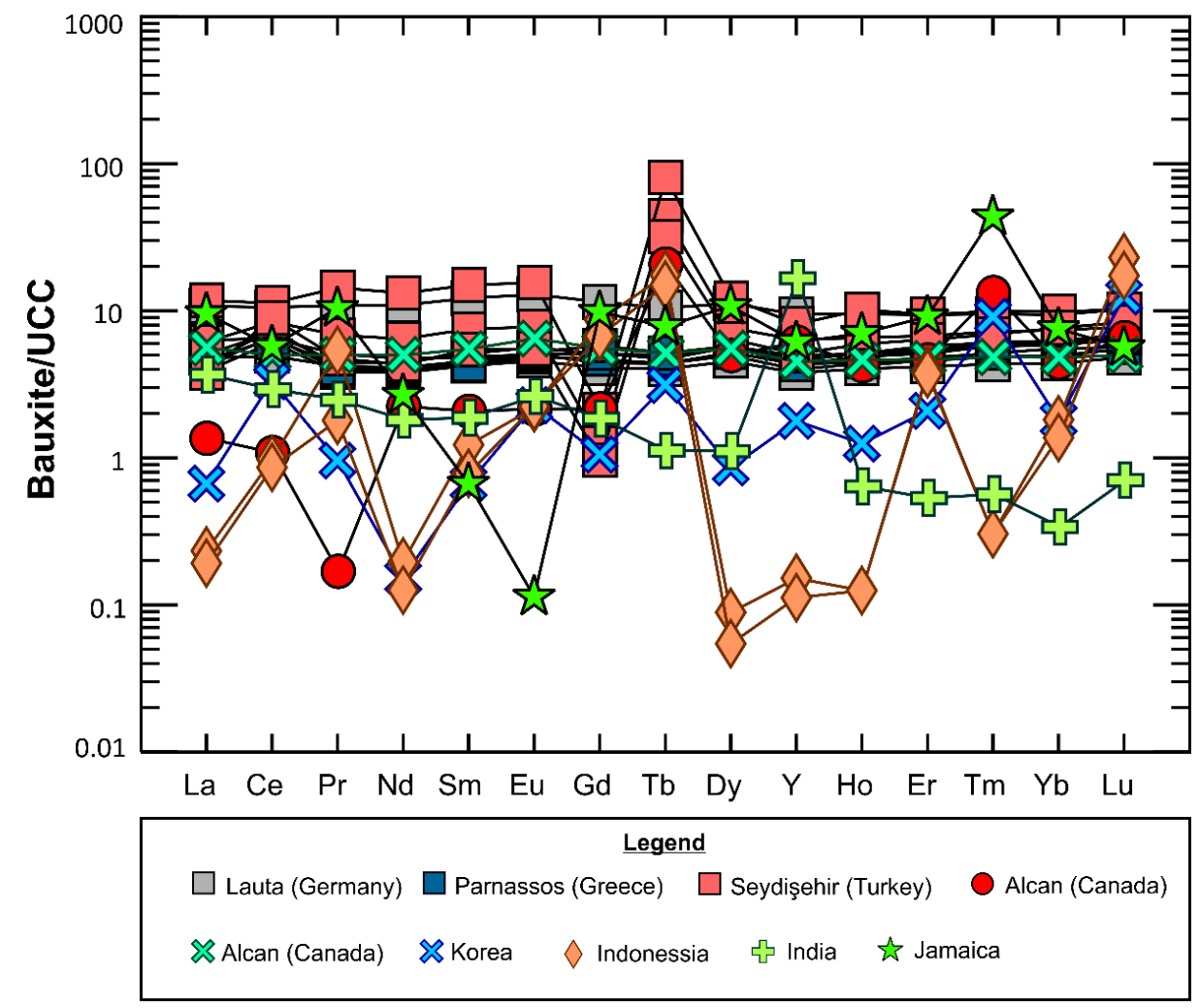

Figure 4. Upper Continental Crust (UCC) normalised-REE patterns for bauxite residue samples from different bauxite deposits around the globe $[8,9,66,68-71]$. 
Red muds from the Lauta deposit (Saxony, Germany) exhibit upper continental crust (UCC)-normalised REE patterns (Figure 4) which show a slight fractionation between LREE and HREE. LREE and more specifically $\mathrm{Ce}$ and La are the most abundant rare earth elements, whereas $\mathrm{Y}$ and Sc present remarkable contents. Cerium, in some cases, exhibits positive anomalies, which are potentially attributed to an early-stage immobilisation after liberation from the primary Ce-bearing minerals in the bauxite [8]. The total REE content is equally heterogeneous with concentrations ranging between 758.5 and 1778 ppm [68]. The REE contents of the bauxite residues from the Almásfüzito alumina plant in Hungary are within a range from 280-1050 ppm, whereas goethite and cancrinite are the main REE-bearing minerals [71]. Their upper continental crust (UCC)-normalised patterns are sub-parallel compared to those of the Lauta deposit in Germany. In the same context, the Parnassos bauxites (Greece) have comparable REE compositions with the Almásfüzito deposit (Hungary), which is further reflected on their sub-parallel upper continental crust (UCC)-normalised REE patterns. However, the Parnassos bauxites also present remarkable (positive) Ce anomalies (Figure 4), which are achieved by oxidising conditions during the supergene oxidation processes that converts $\mathrm{Ce}^{3+}$ into $\mathrm{Ce}^{4+}$ [8]. In neutralised Greek bauxite residues, $\mathrm{Sc}$ (III) and $\mathrm{Ce}(\mathrm{IV})$ occur in $\mathrm{Fe}(\mathrm{III})$-rich mineral phases, hematite and goethite [72]. In the Canadian bauxite residue, $0.03 \mathrm{wt} \%$ of Ce was found to be associated with titanium, whereas scandium was found to be amalgamated with iron and aluminum compounds [73]. The Alcan deposit in Canada shows a high fractionation between HREE and LREE, characterised by a higher HREE content, strong positive Tb, Tm anomalies, as well as a strong negative Pr anomaly. Relatively similar upper continental crust (UCC)-normalised HREE-patterns with those from Alcan deposits are documented in the Seydisehuire residues in Turkey. These residues present considerably higher REE contents compared to those of the Alcan deposits and slight fractionations between LREEs and HREEs, characterised by LREE enrichments. The observed Tb anomalies and remarkable enrichments in the Canadian and Turkish bauxite residues can most likely be linked with the extensive weathering processes of the bauxite ores [74]. In the case of Turkish bauxite residues, these processes can be assigned to the predominance of wet, tropical conditions that further enhance the degree of weathering [75,76]. An alternative scenario could also involve the participation of hydrothermal fluids (derived from the adjacent mafic/diabase rocks) in the bauxite weathering processes [76], which have been occasionally linked with the development of $\mathrm{Tb}$ anomalies [77]. Finally, analysed samples from Indian red mud revealed that it contains measurable amounts of LREE i.e., (La, Ce etc.) including Sc and $\mathrm{Gd}$ (as HREE), with over $0.01 \%$ of $\mathrm{Gd}_{2} \mathrm{O}_{3}$ containing a high enrichment of $\mathrm{Fe}_{2} \mathrm{O}_{3}$ (about 54\%) [78].

In a similar context to the aforementioned coal by-products, distribution and enrichment of REEs in red muds is controlled by the content of REEs and the mineralogical composition of the bauxite parent rock, as well as by the physicochemical conditions that occur during the red mud formation. In particular, REE depletions are usually assigned to the effect of leaching processes by meteoric waters [8]. In addition, changes in the oxidation conditions can cause depletions in significant elements such as $\mathrm{Ce}$, which are reflected in the upper continental crust (UCC) diagrams in the form of negative anomalies [8]. In general, the degree of weathering of the bauxite parent rocks is the major geochemical process that results in REE mobilisation and the subsequent precipitation in the bauxite by-products [79]. This process is highly $\mathrm{pH}$-dependant, favouring REE mobilisation under acidic conditions and REE precipitation under neutral to alkaline conditions [76,79].

\section{Geochemical Occurrence of REE in Other Ore Deposits \\ 5.1. Mining Waste}

In their research, Khorasanipour and Rashidi, 2020 [10] concluded that the geochemical pattern of REEs in the mine tailings ( $\Sigma$ REE ranging from 64 to $275 \mathrm{ppm}$ ) collected from the $\mathrm{Cu}$ porphyry sulphide ore deposits in the Sarcheshmeh mine are controlled mainly by the processes that occur in the acidic conditions. Their experimental results showed 
that HREEs have a higher mobility potential than the LREEs. This meant that REE concentrations for the weathered reject waste was $99.0 \mathrm{ppm}$, while for the fresh tailings it was $136.8 \mathrm{ppm}$. The REE concentrations in the mine waste samples from the inactive Santa Lucia mine (pyrite mineralisation), in western Cuba ranged from 16 to 20 ppm (Figure 5; [80]). The authors reported that the NASC-normalised REE patterns of the mine waste showed enrichment in LREE and MREE, relative to HREE. In mine waste from the abandoned São Domingos mine area of the Iberian Pyrite belt, $\Sigma$ REE concentrations ranged from 18.5 to 310.5 ppm [81] with REE upper continental crust (UCC)-normalised enrichment factors measuring relatively low. Waste pile samples from the iron oxide-apatite (IOA) deposits of the Adirondack Highlands in New York present a very high range of $\Sigma$ REE concentrations (11-22,062 ppm) with $\mathrm{Y}, \mathrm{La}, \mathrm{Ce}$ and $\mathrm{Nd}$ being the most abundant [82]. A positive correlation was found between $\mathrm{P}_{2} \mathrm{O}_{5}$, Th and the total REE, indicating that Th-bearing monazite and thorite were associated with the fluorapatite [82]. Pegmatites found in the region are variably enriched in REEs and may add to the total REE endowment of the piles when they are included as part of the waste. These waste piles present the highest median enrichment factor relative to the other mine waste from the Iberian pyrite belt and $\mathrm{Cu}$-porphyry deposits. Finally, in the abandoned mine tailings of Ingurtosu $\mathrm{Pb}-\mathrm{Zn}$ deposits, in southwestern Sardinia, Italy, the maximum $\Sigma$ REE was 300 ppm [83].

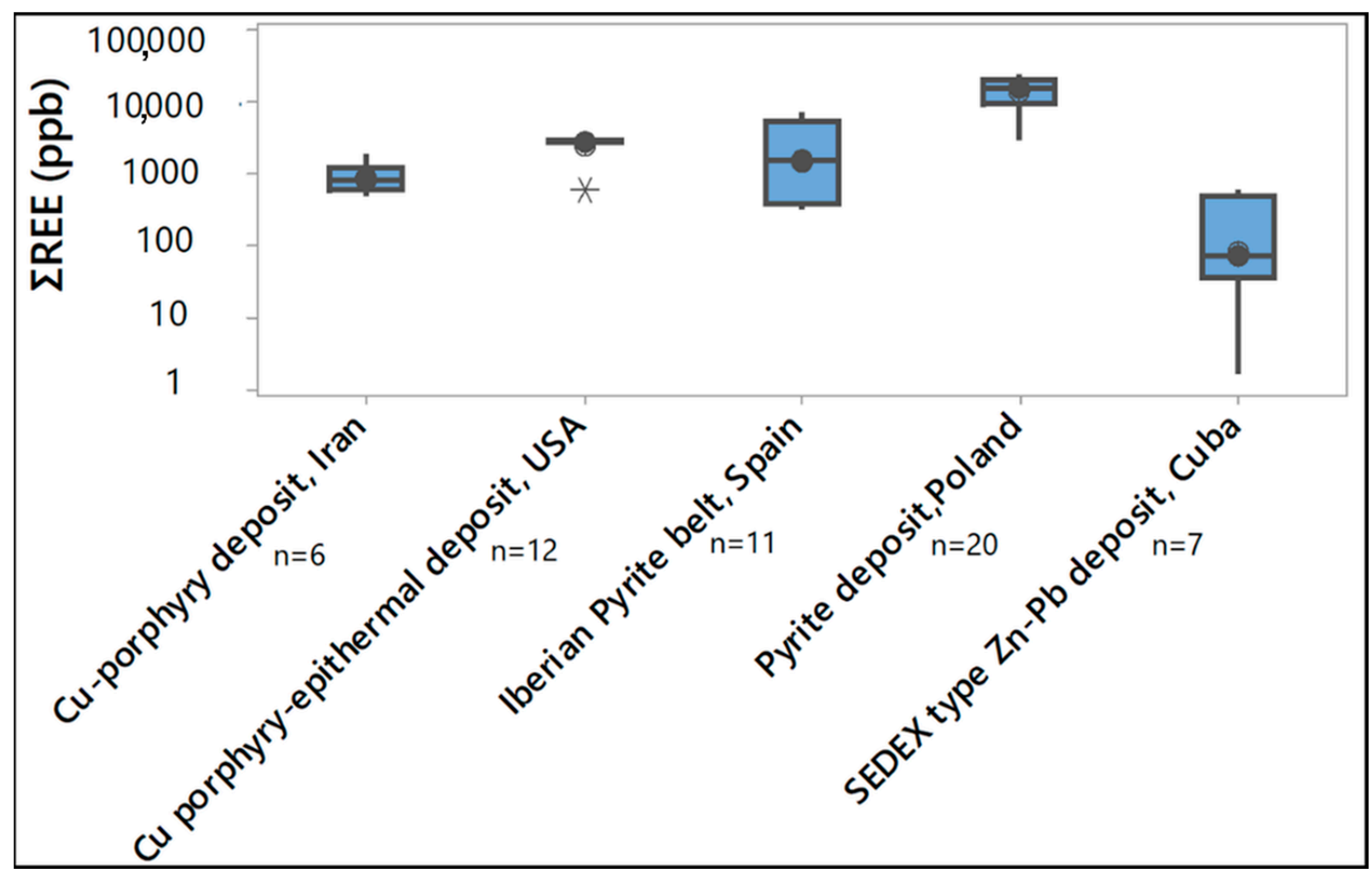

Figure 5. Boxplots of REEs concentration in mine waters from different ore deposits (*: outlier values).

\subsection{Acid Mine Water Discharges}

Acid mine drainage (AMD) is recognised as the main environmental problem derived from mining activities, causing the contamination of soil, water resources and the degradation of aquatic ecosystems [84]. However, AMDs can also be a source of REEs [49]. The AMDs are enriched in REEs during water-rock interaction processes taking place in waste rock dumps and tailings impoundments. In their research, Romero et al. [80] identified that the total dissolved REE concentrations in the acid mine drainage of the inactive Cuban Santa Lucia mine (SEDEX type Zn-Pb deposit), were between 370 and 860 ppb (Figure 5). In the same study, samples taken by an adjacent stream which received the mine's dis- 
charges presented significantly lower concentrations (35-85 ppb) which decreased with an increasing distance from the discharge point. Contrary to what was observed in the solid waste samples, the NASC-normalised REE patterns indicated HREE and MREE enrichment relative to LREE. Research on water samples taken from the acid pit lakes of the Wisniowka mine (quartzite extraction, pyrite mineralisation) in south-central Poland present similar results with REEs concentrations ranging from 2919.7 to 24,840 ppb (Figure 5; [85,86]).

The NASC-normalised REE concentration pattern (Podwiśniówka acid pit lake) shows the prevalence of MREE, especially $\mathrm{Gd}, \mathrm{Eu}$, and Tb, followed by HREE, over LREE. Another significant observation from their results is the strong correlation of $\mathrm{HREE}$ with $\mathrm{SO}_{4}{ }^{2-}$ ions in the Wiśniówka AMD waters. This is in accordance with other studies $[87,88]$ which have shown that REE may be present in the water as prevailing free metal cations and sulphate complexes. Water samples collected from the Wisniowka Duża acid pit lake, located in the same mine but in an area with different geology, reveal the distinct predominance of HREE and $\mathrm{Tb}$ - and Gd-positive anomalies. Soyol-Erdene et al. [89] examined the REE patterns and concentrations in river waters and mine waters (Rio Tinto, Tharsis and Lagunazo) in the Iberian Pyrite Belt (southwest Spain). They identified that the $\sum$ REE concentration in mine water ranged from 297.9 to $7032 \mathrm{ppb}$ with LREE enrichment relative to HREE (Figure 5).

In general, REE concentrations in AMDs from different ore deposits range from tens to thousands to micrograms per liter. This difference in the concentration levels which may also be observed in the same mine is mainly due to the different prevailing $\mathrm{pH}$ and the flow variability during wet and dry seasons. More acidic $\mathrm{pH}$ is related to higher REE concentrations with the mobility of REE mainly constrained by adsorption or co-precipitation processes. Finally, it is observed that during the dry season, this flow decreases and REEs concentrations increase.

The above table is considered an exception to the general behaviour observed in the NASC normalised REE patterns. It illustrates the key role of Al-sulfates for REE retention. In the Portuguese mine, Sao Domingos, also in the Iberian Pyrite Belt, the $\sum$ REE concentration ranged from 118 to 372 ppb, as it was recorded by Perez-Lopez et al. [81]. Similar concentrations were observed in AMD samples from other European metal mines; 372-2846 ppb ( $\mathrm{pH}=1.9-3.0)$ in the Lousal mine of the Iberian pyrite belt in Portugal [90]; and $1600-3000 \mathrm{ppb}(\mathrm{pH}=2.77-3.55)$ in the Ronneburg uranium mine in Germany [91]. In the Sarcheshmeh mine in Iran (porphyry $\mathrm{Cu}$ deposit) (the maximum concentration of REEs was observed in the acidic waters $(\mathrm{pH}=2.5-4.7)$ produced by the weathered tailings after rainfall ( $\Sigma$ REEs of 489 to $1903 \mathrm{ppb}$ ) (Figure 5; [10]). Although $\Sigma$ REEs decreased as the $\mathrm{pH}$ increased, the general trend was compatible with the highest concentration of HREEs rather than LREEs. In the acidic Berkeley pit lake located in the Butte mine $(\mathrm{Cu}$ porphyry-epithermal deposit), USA, the REE profiles showed a depletion in light REE when normalised against NASC, with REE concentrations ranging from 582.8 to $2913.9 \mathrm{ppb}$ (Figure 5). In these acidic conditions, the aqueous speciation of REE is dominated by sulphate complexes. The mobility of REE is more likely constrained by adsorption or coprecipitation with strengite, jarosite, schwertmannite, or other secondary minerals forming in the lake [92].

In addition, it must be mentioned that the flows of AMDs are highly variable during the wet and dry seasons. In the case of AMDs of the Iberian pyrite belt, their flows decrease during summer months by a factor of three to five [93]. This justifies why, during the dry season, the concentrations of REEs are higher than in the wet season. The majority of the samples show MREE and HREE enrichment in acid waters, suggesting the preferential release of HREE in the solution by Fe oxyhydroxides [94]. However, other researchers mention that this is due to the preferential adsorption of the LREE relative to oxyhydroxides [95,96]. Ayora et al. [93] studied in lab scale the behaviour of REE in a multistage sequential treatment of AMD with an REE content of up to $7.9 \mathrm{mg} / \mathrm{L}$, originating from Iberian pyrite belt. REEs were completely retained in the basaluminite precipitates and the decantation vessels of the calcite-DAS passive remediation systems [93]. Therefore, the precipitates resulting from the passive treatment of AMD can be a significant source 
of REEs. In the passive treatment system of the Jales mining site which is an inactive gold mining area in Portugal, the $\Sigma$ REE content in the treated AMDs ranged from 0.951 to $70.4 \mathrm{ppb}$, with the highest concentrations occurring downstream from the discharging point during the summer months. The relatively low concentration of REE in the water at the exit of the open limestone channel is due to their sequestration by ochre sludge [97,98].

\section{Geochemical Occurrence of REEs in Phosphate Waste}

Phosphate rock has about 0.01-0.6 percent of REEs [99]. In phosphate rock, REEs usually substitute calcium ions $\left(\mathrm{Ca}^{2+}\right)$ in apatite mineral, making their concentration proportional to phosphate $\left(\mathrm{P}_{2} \mathrm{O}_{5}\right)$ concentration. The processing chain of phosphate rock results in the production of large quantities of waste such as tailings, waste clay and phosphogypsum [100] which are enriched in REEs, and thus promising secondary sources. For example, approximately 5 tonnes of PG are generated per each tonne of acid produced [101]; therefore, PG is a promising secondary source of REE. Phosphogypsum presents a high range of REE concentrations with a $\Sigma$ REO content ranging from 415.3 to 2096.2 ppm (Table S1) [102-104]. The highest enrichment factors are observed mainly for LREE with high enrichment factors, exceeding 10 in some cases (Figure 6). The chemical composition of PG can vary depending on the nature of the phosphate rock, the type of the acid processing method and the efficiency of the plant operation. According to Walawalkar et al., 2016 [105], Y, La, Ce, Nd, Sm, and Pr were detected in both elemental as well as oxide form in PG.

Flotation tailings are major by-products of the phosphate mining processes, commonly deposited in surface ponds or waste rocks, and are a remarkable secondary source of REEs and other critical raw materials (e.g., tungsten; [106,107]). These materials have caused an increasing research interest over the last 20 years, regarding their REE contents and their subsequent recoverability [106]. Research results suggest that during the ore beneficiation process $10-\sim 25 \%$ of the total REEs are concentrated into tailings [104,108], hosted within minerals such monazite ( 10 TREO), apatite ( $6 \%$ TREO), allanite ( 5\% TREO) and pyrochlore ( 4\% TREO; [104]). In general, the modal mineralogy of tailings is highly linked with the mineralogical composition of the ore deposit and concentrate.

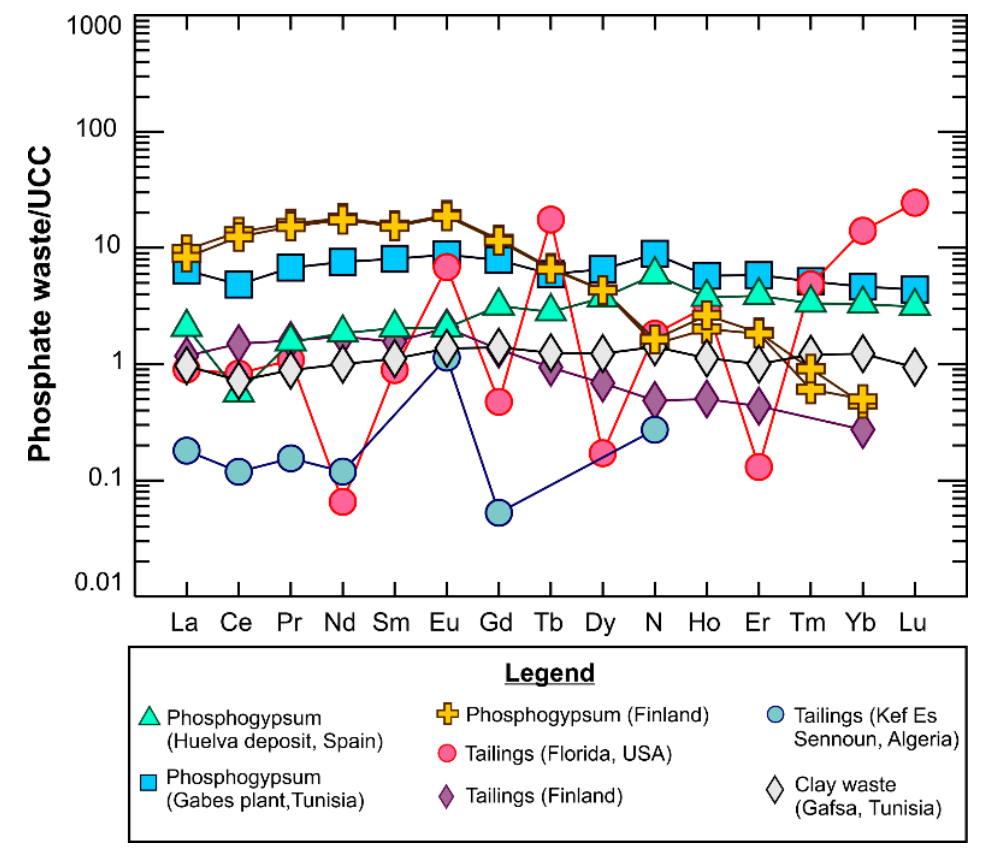

Figure 6. Upper continental crust (UCC) and normalised REE patterns of phosphatic mining wastes [102-104,109-111]. 
Analysis of the REE content of Florida (USA) tailings [110] shows a slight fractionation between LREE $(\Sigma$ LREE $=8.94 \mathrm{ppm})$ and HREE $(\Sigma$ HREE $=43.1 \mathrm{ppm}$; LREE $>$ MREE $>$ HREE $)$, whereas their $\Sigma$ REY and REO content corresponds to 196.2 and $232 \mathrm{ppm}$, respectively. Their upper continental crust-normalised REE patterns exhibit positive Eu anomalies, which are plausibly attributed to the presence of plagioclase. Regarding the major REE carriers, these are most likely the phosphate mineral phases, and mainly franolite, monazite and xenotime [110]. Floatation tailings from Finland show remarkable fractionation between LREE $(\Sigma$ LREE $=187.3 \mathrm{ppm})$ and HREE $(\Sigma$ HREE $=1.9 \mathrm{ppm}$; LREE $>$ MREE $>$ HREE $)$ characterised by slight positive Eu anomalies. Their $\Sigma$ REY and REO contents are $216.9 \mathrm{ppm}$ and $254.6 \mathrm{ppm}$, respectively. The major REE-bearing mineral phases are apatite, monazite, zircon, allanite and pyrochlore [104], whereas the slight positive Eu anomalies could be assigned to the presence of plagioclase as the accessory mineral phase. The analyses of phosphatic tailings from the Kef Es Sennoun (Algeria) deposits [111], show considerably lower $\Sigma$ LREE content, compared to those of the other studied regions, but are characterised by strong positive $\mathrm{Eu}$ anomalies in the upper continental crust-normalised REE patterns (Figure 5). In addition, their geochemical data are restricted only to the LREE and some of the MREE; hence their analysed $\Sigma$ LREE and MREE content is 17.2 and $7.2 \mathrm{ppm}$ respectively, whereas their $\Sigma$ REO is $29.1 \mathrm{ppm}$.

Phosphatic clays (slimes or waste clays) are also by-products, which are derived from the mining of phosphate ores [108]. Waste clays are considered important and critical metal, $\mathrm{P}$ and REE-reserves and their exploitation causes an increasing interest in the industrial sector [112]. This is supported by the fact that during the phosphate ore beneficiation almost $40 \%$ of the total REE content is distributed to the waste clays [108]. In many cases, waste clays potentially exhibit relatively low REE concentrations; however, even in such cases their large quantities provide remarkable amounts of REEs that can be extracted by implementing efficient techniques [113]. For example, in Florida (USA) more than 20 tonnes of waste clay is produced from the exploitation of phosphate rocks on annual scale [114]. Similarly, with the above-mentioned tailings, their chemical composition and the REE content of waste clays are substantially associated with their mineralogical composition. In this context, their mineralogical components can be distinguished into clay (such as smectite, kaolin and illite) and non-clay minerals (e.g., quartz, dolomite and apatite; [112]). Analyses of waste clay material from the Gafsa deposits in Tunisia [109] show relatively flat upper continental crust-normalised patterns, whereas their $\Sigma R E Y$ and $\Sigma$ REO components are $161.5 \mathrm{ppm}$ and $191.6 \mathrm{ppm}$, respectively. In addition, their LREEUCC-normalised patterns seem to be sub-parallel compared to those of the Finish tailings. The most common REE-bearing mineral phase of the Algerian clay wastes is fluoroapatite $(>65 \%)$, which is the major REE-carrier [109].

\section{REE Potential of Mining Waste and Mine Water}

The economic importance of $\mathrm{Nd}$ and $\mathrm{Dy}$ has been underlined by several recent studies due to the increased demand for $\mathrm{NdFeB}$ magnets in hybrid and electric vehicles $[115,116]$. On the other hand, the supply of $\mathrm{La}$ and Ce is predicted to exceed demand [4]. It is forecasted that in China the highest potential demand for REEs in 2030 will reach 315 thousand tonnes for the supply of automotive electrification, accounting for $22 \%$ of world production during that period. In particular, it is estimated that $\mathrm{Nd}, \mathrm{Dy}, \mathrm{Ce}, \mathrm{Pr}$, and La will account for $99 \%$ of the total demand [117].

For the evaluation of REE-rich raw materials, it is necessary to consider the individual REE composition, as the different mining wastes may have different REE distribution patterns. For the comparative evaluation of the mining waste containing greater than $1000 \mathrm{ppm}$ of REO, a scatter plot (Figure 7), where the $y$-axis is the percentage of critical elements in total REY, and the $x$-axis represents the outlook coefficient (Coutl), is developed as proposed by Seredin and Dai, 2012 [2]. Fly ash and coal ash have the highest industrial potential for REE extraction (Figure 7) with the percentage of critical metals greater than $30 \%$ and Coutl ranging from 0.7 to 1.1. Bauxite residue follows this figure with the 
percentage of critical metals greater than $25 \%$ and the Coutl ranging from 0.5 to 0.97 . The mine tailings originating from iron oxide-apatite deposits [82] have a percentage of critical metals ranging from $12.6 \%$ to $29.6 \%$ and a Coutl from 0.26 to 0.97 respectively. Fly ash, coal ash, bauxite residue and phosphogypsum present high percentages of critical REEs (up to $41 \%$ ).
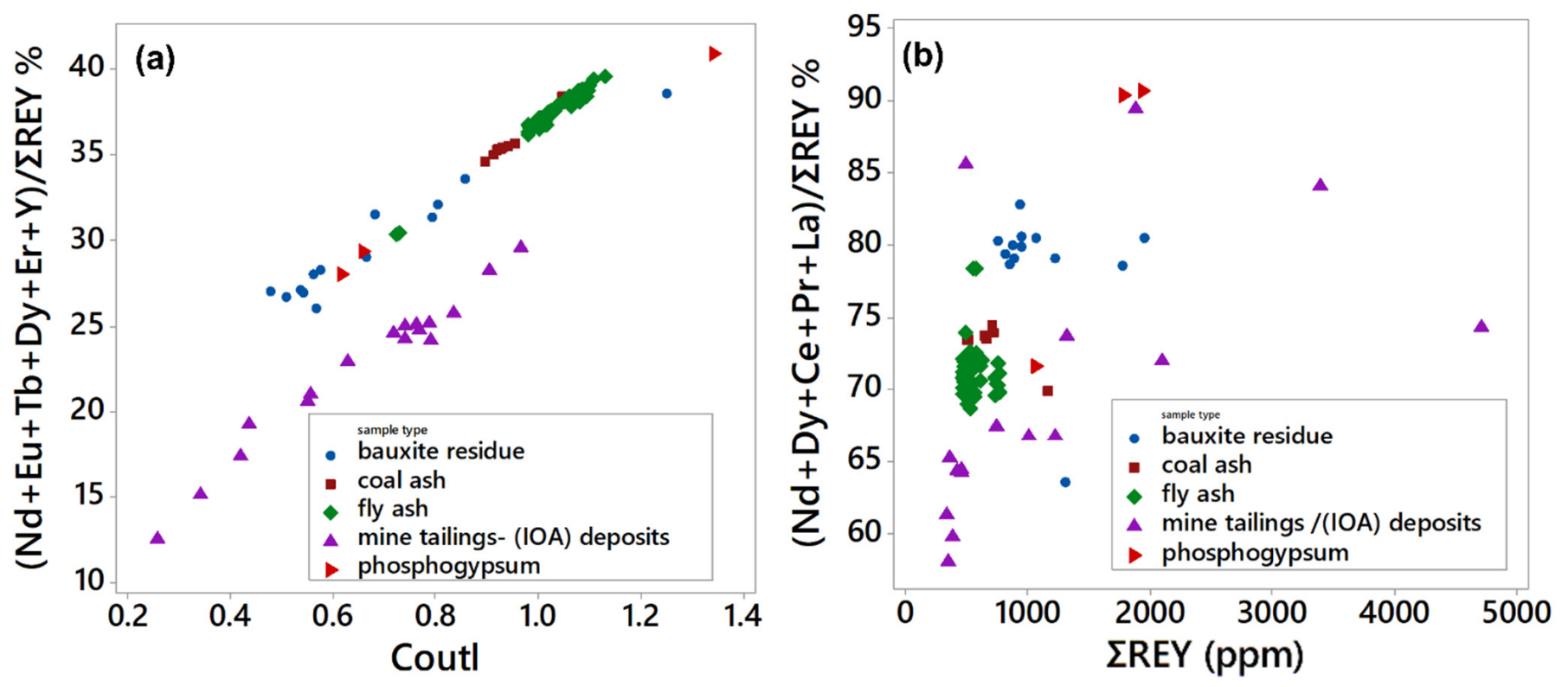

Figure 7. (a) Percentage of critical elements vs. Coutl for different types of solid mining waste with a total REO content $>1000$ ppm. (b) Percentage of critical elements for the market of electromobility vs. $\Sigma$ REY for different types of solid mining waste with a total REO content $>1000$ ppm.

To further assess the industrial potential for the market of electromobility, a similar plot (Figure 7) for mining waste exhibiting REO concentrations greater than $1000 \mathrm{ppm}$ is also developed, according to the results of Li et al. [117], who concluded that Nd, Dy, Ce, $\mathrm{Pr}$, and $\mathrm{La}$ are considered as critical elements. It is observed that for all the types of mining waste, the percentage of critical metals for electromobility is greater than $60 \%$ of the total REY content (Figure 7). The percentage of mine tailings of IOA deposits ranges from 59.8\% to $89.5 \%$, the percentage of bauxite residues ranges from $63.6 \%$ to $82.8 \%$, fly ash and coal ash percentages range from $68.7 \%$ to $78.4 \%$ and from $69.9 \%$ to $74.5 \%$, and phosphogypsum ranges from $71.2 \%$ to $90.7 \%$.

Nevertheless, apart from the content of critical REEs, another significant factor to assess the industrial REE potential of mining waste is the availability of large quantities. According to the European Coal Combustion Products Association (ECOBA) statistics, the amount of coal combustion by-products produced in European power plants in 2016 was approximately 40 million tonnes, of which $63.8 \%$ was fly ash and $9 \%$ was bottom ash. In US, the amount of fly ash which is not reused is approximately 27 million tonnes per year [23]. Furthermore, in the U.S. coal ash is disposed of in approximately 1000 landfills, which have been accumulating coal combustion residuals for several years. In the Polish landfills, during 2016, 309.26 million tonnes of deposits were found, of which 26 million tonnes were the deposited coal ash and the rest were dust-slag compounds from the wet treatment of furnace waste. Every year, about 150 million tonnes of bauxite residues are produced worldwide. However, less than 2 million tonnes are recycled [118].

In the case of coal AMD discharges, the percentage of critical metals for the electromobility market ranges from $13.3 \%$ to $80.6 \%$ with a median value of $57.1 \%$ of total REE content (Figure 8). For the respective percentage for ore mining (pyrite and Cu porphyry mineralisation), AMD discharges are higher than coal mine drainage, which varies from $55 \%$ to $83.9 \%$. The range of $\Sigma$ REE concentrations in AMD discharges is much lower (1-25 ppm) than the 
respective solid waste (>1000 ppm). Nevertheless, the REE potential of AMDs is promising when considering the frequency and the flow rates of these discharges. For example, in the Appalachian coal basin a total of about 538 metric tonnes of REY is generated per year in a dissolved state, approximately $83 \%$ of which consists of acidic discharges $(\mathrm{pH}<5)$ [51]. Additionally, it is roughly estimated that in the Iberian pyrite belt 70 to 100 tonnes of $\mathrm{REY}_{2} \mathrm{O}_{3}$ are annually generated [93]. These AMDs are mainly discharged from galleries, open pits, and waste dumps. The recorded flows are highly variable, i.e., from 0.1 to more than $100 \mathrm{~L} / \mathrm{s}$, with higher flow rates occurring in the wet season.

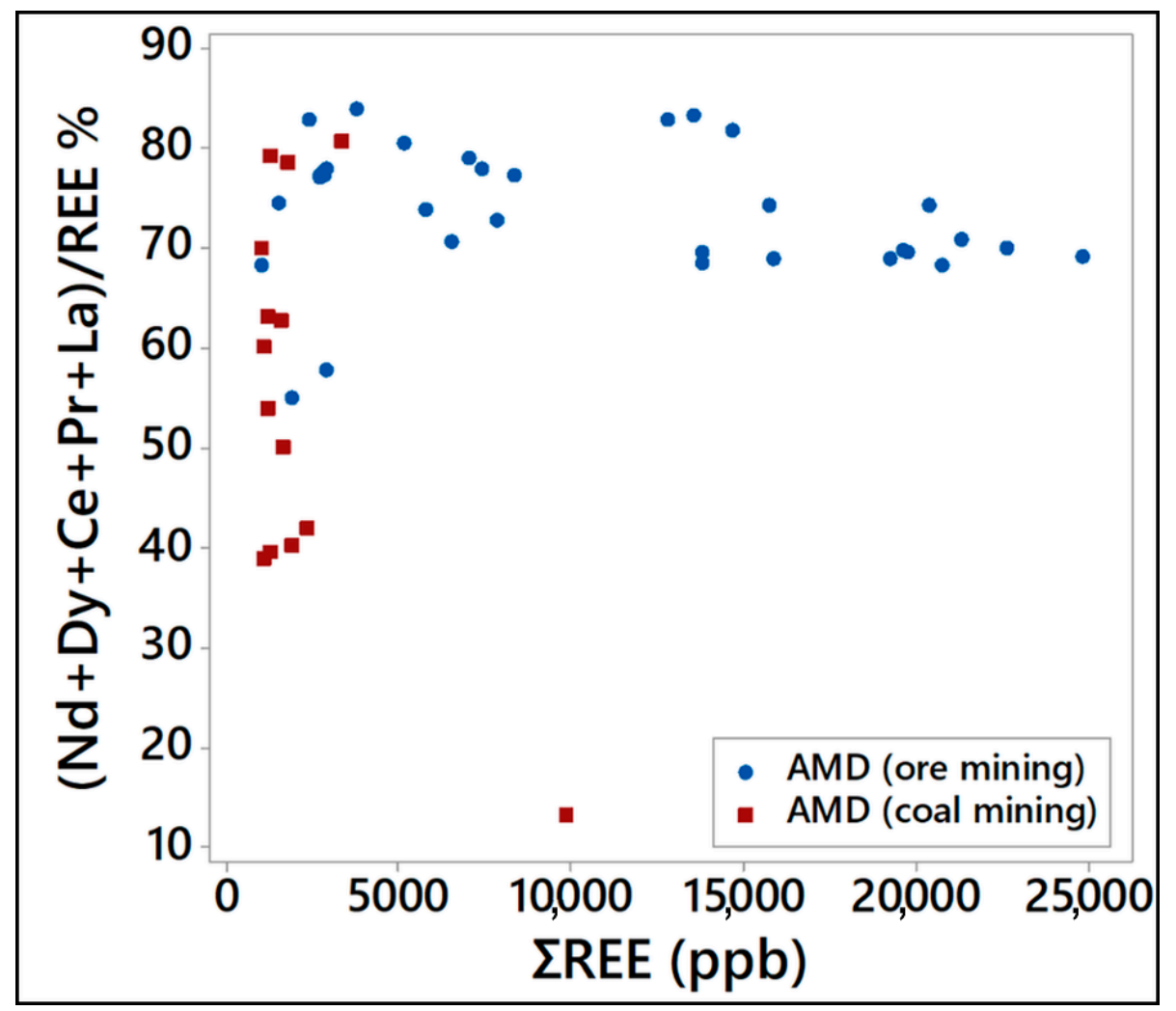

Figure 8. Percentage of critical elements for the market of electromobility vs. $\Sigma$ REE for acid mine drainage discharges from coal and ore mining with a total REE content $>1000 \mathrm{ppb}$.

The recovery of REEs from AMD discharges seems to be more beneficial if it is coupled with passive remediation systems, as REEs are retained in treatment precipitates such as basaluminite residues which are easily dissolved in weak acids [93]. Therefore, new technologies, coupling both the recovery of REE and remediation of AMD, must be investigated.

Another important factor for the recovery of REE from mining waste is the proper management of multiple secondary waste streams generated during the process of critical element extraction. In particular, it is well-known that toxic trace elements may be highly enriched in coal-hosted ore deposits and fly ashes, and, thus, could lead to adverse effects on the environment and on human health. For example, the fly ash derived from the Wulangtua Ge-rich coals contains up to 21,795 ppm As, 15,568 ppm F, 137 ppm Tl, and $160 \mathrm{ppm} \mathrm{Hg} \mathrm{[119].} \mathrm{The} \mathrm{Lincang} \mathrm{fly} \mathrm{ash} \mathrm{derived} \mathrm{from} \mathrm{the} \mathrm{Ge-rich} \mathrm{coal} \mathrm{contains} \mathrm{up} \mathrm{to}$ 5539 ppm Pb, 279 ppm Cs, 7955 ppm Zn, 894 ppm Be, and 106.5 ppm Cd [119,120], as well as highly elevated Th and $U$ in coal-hosted REE deposits [41]. In the case of bauxite residues, Th is also associated with LREE phases, particularly with Ce predominant ferrotitanates [69]. As a result, the developed recovery technologies should take into account the existence of such toxic metals. 
Finally, the main advantages of using mining waste as feedstock for REE production include: (1) large available quantities, (2) no need for REE mining permits, (3) the environmental mitigation of mining wastes, and (4) the utilisation of potential waste materials. As a result, the production of rare earth metal resources for clean energy development during coal and ore exploitation will promote societal progression on the "green road".

\section{Conclusions and Future Research}

Fly ash, coal ash, bauxite residue and phosphogypsum present high percentages of critical REEs with respect to the total REE content demonstrating promising secondary resources for REE extraction. According to the present literature review, all the studied types of mining waste present a high degree of heterogeneity regarding the enrichment and distribution of individual rare earth elements.

The enrichment of the individual REEs in coal combustion by-products varies among different coal basins, which are attributed to the different genetic type of the primary coal. The REE concentrations in the coal ashes from the different coal basins range from $77 \mathrm{ppm}$ in to $1175 \mathrm{ppm}$ whereas, in fly ash, $\Sigma$ REE concentrations range from $91.8 \mathrm{ppm}$ to $775.5 \mathrm{ppm}$. In both bottom and fly ashes, the aluminosilicate fraction seems to be the most enriched in REE regardless of the primary coal origin. In coal dumps, $\Sigma$ REE concentrations are much lower, ranging from 32 to $379 \mathrm{ppm}$, with phosphate and clay minerals being the main REE hosts. The observed positive $\mathrm{Eu}$ anomalies are most likely assigned to the presence of plagioclase crystals, whereas the LREE values are linked with the occurrence of REE-bearing minerals such as clay minerals, monazite and apatite. Considering the large available quantities, future research should include an extensive investigation of the bottom ash and fly ash stockpiles homogeneity in terms of individual REE distribution.

The total REE concentration in bauxite residues from different deposits ranges from 137.2 to $1957.7 \mathrm{ppm}$. The enrichment of REE in bauxite residue is dependent on the REE content of the primary bauxite ore. In many cases, the observed positive Ce anomalies (e.g., Parnassos bauxites, Greece) resulted from supergene oxidation processes that led to the conversion of $\mathrm{Ce}^{3+}$ to $\mathrm{Ce}^{4+}$. On the other hand, the Bayer process resulted in mineralogical transformations which had an impact on the REE-bearing minerals in the bauxite residue. Among these secondary REE-bearing minerals are the LREE ferrotitanates $(\mathrm{REE}, \mathrm{Ca}, \mathrm{Na})(\mathrm{Ti}, \mathrm{Fe}) \mathrm{O}_{3}$ and $(\mathrm{Ca}, \mathrm{Na})(\mathrm{Ti}, \mathrm{Fe}) \mathrm{O}_{3}$, and $\mathrm{Fe}(\mathrm{III})$-rich mineral phases (hematite, goethite). On the contrary, HREE remain bound to the primary minerals such as monazite. The extraction of REE as a by-product of aluminium production from bauxite residues appears to have significant potential. Nevertheless, further research is required regarding the mineralogical transformations during the Bayer process and subsequent re-distribution of REEs.

The total REE concentrations in mine waste piles from iron oxide-apatite deposits range from 11 to 22,062 ppm with Th-bearing monazite being the main mineral phase. On the other hand, in mine tailings from Cu-porphyry and massive sulphide deposits, $\Sigma$ REE ranged from 64 to $275 \mathrm{ppm}$ and from 16 to $310 \mathrm{ppm}$, respectively. In general, there are scarce data regarding REE mineralogy in such mine tailings and further investigations are required to assess their REE potential.

Phosphatic mining wastes exhibit remarkable REE contents. Phosphogypsum tends to exhibit higher REE values compared to those of tailings and clay wastes. Phosphate minerals such as apatite ( $\sim 6 \%$ TREO), monazite ( 10 TREO), allanite $(\sim 5 \%$ TREO) are the most common REE-carriers. The observed Eu anomalies are plausibly assigned to the presence of plagioclase, which potentially occurs in the form of an accessory mineral phase. The large quantities (which in the case of waste clays reaches up to 20 tonnes) of these mining by-products provide the potential to exploit and recover high amounts of REEs.

In general, considering the comparative evaluation for critical metals and the main REE-bearing mineralogical phases for each type of mining waste, it can be concluded that oxides in bauxite residues and aluminosilicates in fly ash and coal ash have a greater potential for exploration than phosphate minerals such as monazite. 
Furthermore, the total REE content in mine discharges from different coal and ore mining areas around the globe is also characterised by a high range varying from 0.25 to $9879 \mathrm{ppb}$ and 1.6 to $24,840 \mathrm{ppb}$, respectively. Notably, REE concentrations can also vary greatly within the same mine. This is because the specific geochemical processes (acidic dissolution, precipitation, sorption, dilution, etc.) that take place in the mine, control the enrichment and the distribution of REEs in mine water. The $\mathrm{pH}$ of mine discharges is the most significant parameter controlling both REEs' release from the associated minerals, as well as the speciation of REEs in the aqueous phase, with total REE concentrations increasing as their $\mathrm{pH}$ decreases due to the acidic dissolution of REE-bearing minerals. The range of $\Sigma R E E$ concentrations in AMD discharges is much lower than the respective solid waste. Nevertheless, the REE potential of AMDs seems to be promising when considering the frequency and the flow rates of these discharges. Therefore, future research has to be focused on the development of coupled technologies which will target both the treatment and optimal extraction of REE from mine discharges. In particular, the recovery of REE from mine discharges and associated precipitates is promising if it is combined with passive remediation technologies which target the separate concentration of REEs for further recovery. Finally, the developed technologies should consider the environmental management of secondary waste streams which may contain toxic and/or radioactive elements such as Th and $\mathrm{U}$.

Supplementary Materials: The following are available online at https://www.mdpi.com/article/ 10.3390 / $\min 11080860$ / s1, Table S1: REE concentrations in mining waste and by-products; Table S2: REE concentrations in mine water discharges.

Author Contributions: K.P. shaped the main idea of the article, organised the literature, developed the database, created the figures and participated in writing and editing of the manuscript; V.G. organised the literature and participated in the writing and editing of the manuscript; C.K. created the figures and participated in the writing and editing of the manuscript; N.K. participated in writing and editing of the manuscript; P.K. participated in writing and editing of the manuscript; P.P. participated in writing and editing of the manuscript. All authors have read and agreed to the published version of the manuscript.

Funding: This research received no external funding.

Data Availability Statement: The data presented in this study are available in the supplementary material.

Acknowledgments: We would like to thank the three anonymous reviewers for their constructive comments and suggestions that significantly improved the quality of the paper. Special thanks are also expressed to the editor. We would like also to thank the geologists, Eleftheria Karampetsou and Nota-Elpida Tsekoura for their support.

Conflicts of Interest: The authors declare no conflict of interest.

\section{References}

1. Goodenough, K.M.; Schilling, J.; Jonsson, E.; Kalvig, P.; Charles, N.; Tuduri, J.; Deady, E.A.; Sadeghi, M.; Schiellerup, H.; Müller, A.; et al. Europe's rare earth element resource potential: An overview of REE metallogenetic provinces and their geodynamic setting. Ore Geol. Rev. 2016, 72, 838-856. [CrossRef]

2. Blissett, R.S.; Smalley, N.; Rowson, N.A. An investigation into six coal fly ashes from the United Kingdom and Poland to evaluate rare earth element content. Fuel 2014, 119, 236-239. [CrossRef]

3. Seredin, V.V.; Dai, S. Coal deposits as potential alternative sources for lanthanides and yttrium. Int. J. Coal Geol. $2012,94,67-93$. [CrossRef]

4. Goodenough, K.M.; Wall, F.; Merriman, D. The Rare Earth Elements: Demand, Global Resources, and Challenges for Resourcing Future Generations. Nat. Resour. Res. 2018, 27, 201-216. [CrossRef]

5. U.S. Geological Survey. Mineral Commodity Summaries; U.S. Geological Survey: Reston, VA, USA, 2020 ; p. 200.

6. Wall, F. Rare earth elements. In Critical Metals Handbook; Gunn, G., Ed.; John Wiley \& Sons: Nottingham, UK, $2014 ;$ pp. 312-339.

7. Kumari, A.; Jha, M.K.; Pathak, D.D. Review on the Processes for the Recovery of Rare Earth Metals (REMs) from Secondary Resources. In Rare Metal Technology; Springer: Berlin/Heidelberg, Germany, 2018. 
8. Deady, E.A.; Mouchos, E.; Goodenough, K.; Williamson, B.J.; Wall, F. A review of the potential for rare-earth element resources from European red muds: Examples from Seydisehir, Turkey and Parnassus-Giona, Greece. Mineral. Mag. 2016, 80, 43-61. [CrossRef]

9. Abhilash, S.S.; Meshram, P.; Pandey, B.D.; Behera, P.K.; Satpathy, B.K. Red Mud: A Secondary Resource for Rare Earth Elements. In Proceedings of the International Bauxite, Alumina \& Aluminium Symposium, Visakhapatnam, India, 28 November 2014; pp. 148-162.

10. Khorasanipour, M.; Rashidi, S. Geochemical fractionation pattern and environmental behaviour of rare earth elements (REEs) in mine wastes and mining contaminated sediments; Sarcheshmeh mine, SE of Iran. J. Geochem. Explor. 2020, 210, 106450. [CrossRef]

11. Vass, C.R.; Noble, A.; Ziemkiewicz, P.F. The Occurrence and Concentration of Rare Earth Elements in Acid Mine Drainage and Treatment Byproducts. Min. Metall. Explor. 2019, 36, 917-929.

12. Reinhardt, N.; Proenza, J.A.; Villanova-de-Benavent, C.; Aiglsperger, T.; Bover-Arnal, T.; Torró, L.; Salas, R.; Dziggel, A. Geochemistry and Mineralogy of Rare Earth Elements (REE) in Bauxitic Ores of the Catalan Coastal Range, NE Spain. Minerals 2018, 8, 562. [CrossRef]

13. Franus, W.; Wiatros-Motyka, M.M.; Wdowin, M. Coal fly ash as a resource for rare earth elements. Environ. Sci. Pollut. Res. 2015, 22, 9464-9474. [CrossRef]

14. DG Environment, European Commission. Management of Mining, Quarrying and Ore-Processing Waste in the European Union; Bureau de Recherches Géologiques et Minières (BRGM): Orléans, France, 2001; p. 79.

15. Taylor, S.R.; McLennan, S.M. The Continental Crust: Its Composition and Evolution; U.S. Department of Energy: Washington, DC, USA, 1985.

16. Seredin, V.V.; Finkelman, R.B. Metalliferous coals: A review of the main genetic and geochemical types. Int. J. Coal Geol. 2008, 76, 253-289. [CrossRef]

17. Yuan, Y.; Tang, S.; Zhang, S.; Yang, N. Mineralogical and Geochemical Characteristics of Trace Elements in the Yongdingzhuang Mine, Datong Coalfield, Shanxi Province, China. Minerals 2018, 8, 297. [CrossRef]

18. Fiket, Z.; Medunic, G.; Turk, M.F.; Kniewald, G. Rare earth elements in superhigh-organic-sulfur Rasa coal ash (Croatia). Int. J. Coal Geol. 2018, 194, 1-10. [CrossRef]

19. Dai, S.; Xie, P.; Jia, S.; Ward, C.R.; Hower, J.C.; Yan, X.; French, D. Enrichment of U-Re-V-Cr-Se and rare earth elements in the Late Permian coals of the Moxinpo Coalfield, Chongqing, China: Genetic implications from geochemical and mineralogical data. Ore Geol. Rev. 2017, 80, 1-17. [CrossRef]

20. Finkelman, R.B.; Dai, S.; French, D. The importance of minerals in coal as the hosts of chemical elements: A review. Int. J. Coal Geol. 2019, 212, 103251. [CrossRef]

21. Izquierdo, M.; Koukouzas, N.; Touliou, S.; Panopoulos, K.D.; Querol, X.; Itskos, G. Geochemical controls on leaching of lignite-fired combustion by-products from Greece. Appl. Geochem. 2011, 26, 1599-1606. [CrossRef]

22. Hussain, R.; Luo, K. Geochemical Evaluation of Enrichment of Rare-Earth and Critical Elements in Coal Wastes from Jurassic and Permo-Carboniferous Coals in Ordos Basin, China. Nat. Resour. Res. 2020, 29, 1731-1754. [CrossRef]

23. Taggart, R.K.; Hower, J.C.; Dwyer, G.S.; Hsu-Kim, H. Trends in the Rare Earth Element Content of U.S.-Based Coal Combustion Fly Ashes. Environ. Sci. Technol. 2016, 50, 5919-5926. [CrossRef] [PubMed]

24. Hall, A.; Ahmed, Z. Rare earth content and origin of rodingites. Chem. Erde 1984, 43, $28-51$.

25. Koutsovitis, P. Gabbroic rocks in ophiolitic occurrences from East Othris, Greece: Petrogenetic processes and geotectonic environment implications. Miner. Pet. 2012, 104, 249-265. [CrossRef]

26. Mubarak, H.S.; Azer, M.K.; Surour, A.A.; Moussa, H.E.; Asimow, P.D.; Kabesh, M.M.L. Mineralogical and geochemical study of rodingites and associated serpentinized peridotite, Eastern Desert of Egypt, Arabian-Nubian Shield. Lithos 2020, 374-375, 105720. [CrossRef]

27. Erarslan, C.; Orgun, Y. Mineralogical and geochemical characteristics of coal ash from the Northwest Thrace region, Turkey: A case study. Arab. J. Geosci. 2017, 10, 221. [CrossRef]

28. Kolker, A.; Scott, C.; Hower, J.C.; Vazquez, J.A.; Lopano, C.L.; Dai, S. Distribution of rare earth elements in coal combustion fly ash, determined by SHRIMP-RG ion microprobe. Int. J. Coal Geol. 2017, 184, 1-10. [CrossRef]

29. Honaker, R.; Yang, X.; Chandra, A.; Zhang, W.; Werner, J. Hydrometallurgical Extraction of Rare Earth Elements from Coal; Springer International Publishing: Berlin, Germany, 2018.

30. Pan, J.; Zhou, C.; Liu, C.; Tang, M.; Cao, S.; Hu, T.; Ji, W.; Luo, Y.; Wen, M.; Zhang, N. Modes of occurrence of rare earth elements in coal fly ash-A case study. Energy Fuels 2018, 32, 9738-9743. [CrossRef]

31. Liu, P.; Huang, R.; Tang, Y. Comprehensive Understandings of Rare Earth Element (REE) Speciation in Coal Fly Ashes and Implication for REE Extractability. Environ. Sci. Technol. 2019, 53, 5369-5377. [CrossRef]

32. Lin, R.; Howard, B.H.; Roth, E.A.; Bank, T.L.; Granite, E.J.; Soong, Y. Enrichment of rare earth elements from coal and coal by-products by physical separations. Fuel 2017, 200, 506-520. [CrossRef]

33. Montross, S.N.; Verba, C.A.; Chan, H.L.; Lopano, C. Advanced characterization of rare earth element minerals in coal utilization byproducts using multimodal image analysis. Int. J. Coal Geol. 2018, 195, 362-372. [CrossRef]

34. Valentim, B.; Abagiu, A.T.; Anghelescu, L.; Flores, D.; French, D.; Gonçalves, P.; Guedes, A.; Popescu, L.G.; Predeanu, G.; Ribeiro, J.; et al. Assessment of bottom ash landfilled at Ceplea Valley (Romania) as a source of rare earth elements. Int. J. Coal Geol. 2019, 201, 109-126. [CrossRef] 
35. Zhang, W.; Honaker, R. Calcination pretreatment effects on acid leaching characteristics of rare earth elements from middlings and coarse refuse material associated with a bituminous coal source. Fuel 2019, 249, 130-145. [CrossRef]

36. Wang, X. Petrology and geochemistry of the Jurassic coals in southwestern Ordos Basin, China. Energy Explor. Exploit. 2010, 28, 513-530. [CrossRef]

37. Yan, X.; Dai, S.; Graham, I.T.; He, X.; Shan, K.; Liu, X. Determination of Eu concentrations in coal, fly ash and sedimentary rocks using a cation exchange resin and inductively coupled plasma mass spectrometry (ICP-MS). Int. J. Coal Geol. 2018, 191, 152-156. [CrossRef]

38. Wen, X.; Zeng, F.; Zhang, H. Geochemical characteristics of the coal gangues from the Du'erping coal mine, Xishan coalfield, North China. Chin. J. Geochem. 2013, 32, 227-234. [CrossRef]

39. Nowak, J.; Kokowska-Pawlowska, M. Changes in the concentration of some rare earth elements in coal waste. Arch. Min. Sci. 2017, 62, 495-507. [CrossRef]

40. Zhang, W.; Yang, X.; Honaker, R.Q. Association characteristic study and preliminary recovery investigation of rare earth elements from Fire Clay seam coal middlings. Fuel 2018, 215, 551-560. [CrossRef]

41. Dai, S.; Liu, J.; Ward, C.R.; Hower, J.C.; French, D.; Jia, S.; Hood, M.M.; Garrison, T.M. Mineralogical and geochemical compositions of Late Permian coals and host rocks from the Guxu Coalfield, Sichuan Province, China, with emphasis on enrichment of rare metals. Int. J. Coal Geol. 2016, 166, 71-97. [CrossRef]

42. Shahhosseini, M.; Ardejani, F.D.; Ernest, B. Geochemistry of rare earth elements in a neutral mine drainage environment, Anjir Tangeh, northern Iran. Int. J. Coal Geol. 2017, 183, 120-135. [CrossRef]

43. $\mathrm{Li}, \mathrm{X}$.; $\mathrm{Wu}, \mathrm{P}$. Geochemical characteristics of dissolved rare earth elements in acid mine drainage from abandoned high-As coal mining area, southwestern China. Environ. Sci. Pollut. Res. 2017, 24, 20540-20555. [CrossRef] [PubMed]

44. Lefticariu, L.; Klitzing, K.L.; Kolker, A. Rare Earth Elements and Yttrium (REY) in coal mine drainage from the Illinois Basin, USA. Int. J. Coal Geol. 2020, 217, 103327. [CrossRef]

45. Wallrich, I.L.R.; Stewart, B.W.; Capo, R.C.; Hedin, B.C.; Phan, T.T. Neodymium isotopes track sources of rare earth elements in acidic mine waters. Geochim. Cosmochim. Acta 2020, 269, 465-483. [CrossRef]

46. Worrall, F.; Pearson, G. The development of acidic groundwaters in coal-bearing strata: Part I. Rare earth element fingerprinting. Appl. Geochem. 2001, 16, 1465-1480. [CrossRef]

47. Stewart, B.W.; Capo, R.C.; Hedin, B.C.; Hedin, R.S. Rare earth element resources in coal mine drainage and treatment precipitates in the Appalachian Basin, USA. Int. J. Coal Geol. 2017, 169, 28-39. [CrossRef]

48. Hedin, B.C.; Capo, R.C.; Stewart, B.W.; Hedin, R.S.; Lopano, C.L.; Stuckman, M.Y. The evaluation of critical rare earth element (REE) enriched treatment solids from coalmine drainage passive treatment systems. Int. J. Coal Geol. 2019, 208, 54-64. [CrossRef]

49. Kefeni, K.; Msagati, T.A.M.; Mamba, B. Acid mine drainage: Prevention, treatment options, and resource recovery: A review. J. Clean. Prod. 2017, 151, 475-493. [CrossRef]

50. Das, S.K.; Yin, W. The worldwide aluminum economy: The current state of the industry. JOM 2007, 59, 57-63. [CrossRef]

51. Deady, E.; Mouchos, E.; Goodenough, K.; Wall, F. Rare Earth Elements in Karst-Bauxites: A Novel Untapped European Resource? In Proceedings of the European Rare Earth Resources Conference, Milos, Greece, 4-6 September 2014; p. 12.

52. Torró, L.; Proenza, J.A.; Aiglsperger, T.; Bover-Arnal, T.; Villanova-de-Benavent, C.; Rodríguez-García, D.; Ramírez, A.; Rodríguez, J.; Mosquea, L.A.; Salas, R. Geological, geochemical and mineralogical characteristics of REE-bearing Las Mercedes bauxite deposit, Dominican Republic. Ore Geol. Rev. 2017, 89, 114-131. [CrossRef]

53. Vind, J.; Vassiliadou, V.; Panias, D. Distribution of trace elements through the Bayer process and its by-products. In Proceedings of the 35th International ICSOBA Conference, Hamburg, Germany, 2-5 October 2017; pp. 255-267.

54. Borra, C.R.; Blanpain, B.; Pontikes, Y.; Binnemans, K.; Van Gerven, T. Recovery of rare earths and other valuable metals from bauxite residue (red mud): A review. J. Sustain. Metall. 2016, 2, 365-386. [CrossRef]

55. Liu, Z.; Li, H. Metallurgical process for valuable elements recovery from red mud-A review. Hydrometallurgy 2015, 155, 29-43. [CrossRef]

56. Klyucharev, D.S.; Volkova, N.M.; Comyn, M.F. The problems associated with using nonconventional rare-earth minerals. J. Geochem. Explor. 2013, 133, 138-148. [CrossRef]

57. Ochsenkühn-Petropulu, M.; Lyberopulu, T.; Parissakis, G. Direct determination of lanthanides, yttrium and scandium in bauxites and red mud from alumina production. Anal. Chim. Acta 1994, 296, 305-313. [CrossRef]

58. Wagh, A.S.; Pinnock, W.R. Occurrence of scandium and rare earth elements in Jamaican bauxite waste. Econ. Geol. 1987, 82, 757-761. [CrossRef]

59. Binnemans, K.; Jones, P.T.; Blanpain, B.; Van Gerven, T.; Yang, Y.; Walton, A.; Matthias, B. Recycling of rare earths: A critical review. J. Clean Prod. 2013, 51, 1-22. [CrossRef]

60. Bonomi, C.; Cardenia, C.; Yin, P.T.W.; Panias, D. Review of Technologies in the Recovery of Iron, Aluminium, Titanium and Rare Earth Elements from Bauxite Residue (Red Mud). In Proceedings of the 3rd International Symposium on Enhanced Landfill Mining, Lisbon, Portugal, 8-10 February 2016; pp. 259-276.

61. Balomenos, E.; Davris, P.; Pontikes, Y.; Panias, D. Mud2Metal: Lessons Learned on the Path for Complete Utilization of Bauxite Residue through Industrial Symbiosis. J. Sustain. Metall. 2017, 3, 551-560. [CrossRef]

62. Bray, E.L. Bauxite and Alumina, in Metals and Minerals; U.S. Geological Survey: Reston, VA, USA, 2008 ; Volume 1. 
63. Yatsenko, S.P.; Pyagai, I.N. Red mud pulp carbonization with scandium extraction during alumina production. Theor. Found. Chem. Eng. 2010, 44, 563-568. [CrossRef]

64. Fulford, G.D.; Lever, G.; Sato, T. Recovery of Rare Earth elements from Sulphurous Acid Solution by Solvent Extraction. U.S. Patent 5,015,447 A, 14 May 1991.

65. Borra, C.R.; Pontikes, Y.; Binnenmas, K.; Gerven, T.V. Leaching of rare earths from bauxite residue (red mud). Miner. Eng. 2015, 76, 20-27. [CrossRef]

66. Narayanan, R.P.N.; Kazantzis, N.K.; Emmert, M.H. Selective Process Steps for the Recovery of Scandium from Jamaican Bauxite Residue (Red Mud). Sustain. Chem. Eng. 2018, 6, 1478-1488. [CrossRef]

67. Gamaletsos, P.N.; Godelitsas, A.; Kasama, T.; Kuzmin, A.; Lagos, M.; Mertzimekis, T.J.; Göttlicher, J.; Steininger, R.; Xanthos, S.; Pontikes, Y.; et al. The role of nano-perovskite in the negligible thorium release in seawater from Greek bauxite residue (red mud). Sci. Rep. 2016, 6, 21737. [CrossRef]

68. Bolanz, R.M.; Kiefer, S.; Gottlicher, J.; Steininger, R. Hematite $\left(\alpha-\mathrm{Fe}_{2} \mathrm{O}_{3}\right)-\mathrm{A}$ potential Ce $\mathrm{e}^{4+}$ carrier in red mud. Sci. Total Environ. 2018, 622-623, 849-860. [CrossRef]

69. Vind, J.; Malfliet, A.; Blanpain, B.; Tsakiridis, P.E.; Tkaczyk, A.H.; Vassiliadou, V.; Panias, D. Rare Earth Element Phases in Bauxite Residue. Minerals 2018, 8, 77. [CrossRef]

70. Damayanti, R.; Khaerunissa, H. Composition and characteristics of red mud: A case study on Tayan bauxite residue from alumina processing plant at West Kalimantan. Indones. Min. J. 2016, 19, 179-190. [CrossRef]

71. Tóth, T.M.; Schubert, F.; Raucsik, B.; Fintor, K. Mineralogical and Geochemical Constraints of the REE Accumulation in the Almasfuzito Red Mud Depository in Northwest Hungary. Appl. Sci. 2019, 9, 3654. [CrossRef]

72. Rivera, R.M.; Ounoughene, G.; Malfliet, A.; Vind, J.; Panias, D.; Vassiliadou, V.; Binnemans, K.; Van Gerven, T. A Study of the Occurrence of Selected Rare-Earth Elements in Neutralized-Leached Bauxite Residue and Comparison with Untreated Bauxite Residue. J. Sustain. Metall. 2019, 5, 57-68. [CrossRef]

73. Reid, S.; Tam, J.; Yang, M.; Azimi, G. Technospheric Mining of Rare Earth Elements from Bauxite Residue (Red Mud): Process Optimization, Kinetic Investigation, and Microwave Pretreatment. Sci. Rep. 2017, 7, 15252. [CrossRef] [PubMed]

74. Wang, X.; Jiao, Y.; Du, Y.; Ling, W.; Wu, L.; Cui, T.; Zhou, Q.; Jin, Z.; Lei, Z.; Weng, S. REE mobility and Ce anomaly in bauxite deposit of WZD area, Northern Guizhou, China. Chem. Geol. 2013, 133, 103-117. [CrossRef]

75. Maksimovic, Z.; Panto, G. Contribution to the geochemistry of the rare earth elements in the karst-bauxite deposits of Yugoslavia and Greece. Geoderma 1991, 51, 93-109. [CrossRef]

76. Karadă̆, M.M.; Küpeli, Ş.; Arýk, F.; Ahmet, A.; Veysel, Z.; Döyen, A. Rare earth element (REE) geochemistry and genetic implications of the Mortaş bauxite deposit (Seydişehir/Konya-Southern Turkey). Geochemistry 2009, 69, 143-159. [CrossRef]

77. Khosravi, M.; Abedini, A.; Alipour, S.; Mongelli, G. The Darzi-Vali bauxite deposit, West-Azarbaidjan Province, Iran: Critical metals distribution and parental affinities. J. Afr. Earth Sci. 2017, 129, 960-972. [CrossRef]

78. Klauber, C.; Rafe, M.; Powder, G. Bauxite residue issues: II. Options for residue utilization. Hydrometallurgy 2011, 108, 11-32. [CrossRef]

79. Li, Z.; Din, J.; Xu, J.; Liao, C.; Yin, F.; Lü, T.; Cheng, L.; Li, J. Discovery of the REE minerals in the Wulong-Nanchuan bauxite deposits, Chongqing, China: Insights on conditions of formation and processes. J. Geochem. Explor. 2013, 133, 88-102. [CrossRef]

80. Romero, F.M.; Prol-Ledesma, R.M.; Canet, C.; Núñez Alvares, L.; Perez-Vazquez, R. Acid drainage at the inactive Santa Lucia mine, western Cuba: Natural attenuation of arsenic, barium and lead, and geochemical behavior of rare earth elements. Appl. Geochem. 2010, 25, 716-727. [CrossRef]

81. Pérez-López, R.; Delgado, J.; Nieto, J.M.; Márquez-García, B. Rare earth element geochemistry of sulphide weathering in the São Domingos mine area (Iberian Pyrite Belt): A proxy for fluid-rock interaction and ancient mining pollution. Chem. Geol. 2010, 276, 29-40. [CrossRef]

82. Taylor, R.D.; Shah, A.K.; Walsh, G.J.; Taylor, C.D. Geochemistry and Geophysics of Iron Oxide-Apatite Deposits and Associated Waste Piles with Implications for Potential Rare Earth Element Resources from Ore and Historical Mine Waste in the Eastern Adirondack Highlands, New York, USA. Econ. Geol. 2019, 114, 1569-1598. [CrossRef]

83. Medas, D.; Cidu, R.; De Giudici, G.; Podda, F. Geochemistry of rare earth elements in water and solid materials at abandoned mines in SW Sardinia (Italy). J. Geochem. Explor. 2013, 133, 149-159. [CrossRef]

84. Galhardi, J.A.; Bonotto, D. Hydrogeochemical features of surface water and groundwater contaminated with acid mine drainage (AMD) in coal mining areas: A case study in southern Brazil. Environ. Sci. Pollut. Res. 2016, 23, 18911-18927. [CrossRef]

85. Migaszewski, Z.M.; Gałuszka, A.; Dolegowska, S. Extreme enrichment of arsenic and rare earth elements in acid mine drainage: Case study of Wisniowka mining area (south-central Poland). Environ. Pollut. 2019, 244, 898-906. [CrossRef]

86. Migaszewski, Z.M.; Gałuszka, A.; Doleggowska, S. Rare earth and trace element signatures for assessing an impact of rock mining and processing on the environment: Wisniowka case study, south-central Poland. Environ. Sci. Pollut. Res. 2016, 23, 24943-24959. [CrossRef]

87. Leybourne, M.I.; Goodfellow, W.D.; Boyle, D.R.; Hall, G.M. Rapid development of negative Ce anomalies in surface waters and contrasting REE patterns in groundwaters associated with $\mathrm{Zn}-\mathrm{Pb}$ massive sulphide deposits. Appl. Geochem. 2000, 15, 695-723. [CrossRef] 
88. Johannesson, K.H.; Lyons, W.B.; Stetzenbach, K.J.; Byrne, R.H. The solubility control of rare earth elements in natural terrestrial waters and the significance of PO43- and CO32- in limiting dissolved rare earth concentrations: A review of recent information. Aquat. Geochem. 1995, 1, 157-173. [CrossRef]

89. Soyol-Erdene, T.O.; Valente, T.; Grande, J.A.; de la Torre, M.L. Mineralogical controls on mobility of rare earth elements in acid mine drainage environments. Chemosphere 2018, 205, 317-327. [CrossRef] [PubMed]

90. Ferreira da Silva, E.; Bobos, I.; Matos, J.X.; Patinha, C.; Reis, A.P.; Fonseca, E.C. Mineralogy and geochemistry of trace metals and REE in volcanic massive sulfide host rocks, stream sediments, stream waters and acid mine drainage from the Lousal mine area (Iberian Pyrite Belt, Portugal). App. Geochem. 2009, 24, 383-401. [CrossRef]

91. Merten, D.; Geletneky, J.; Bergmann, H.; Haferburg, G.; Kothe, E.; Buchel, G. Rare earth element patterns: A tool for understanding processes in remediation of acid mine drainage. Geochemistry 2005, 65, 97-114. [CrossRef]

92. Gammons, C.H.; Wood, S.A.; Jonas, J.P.; Madison, J.P. Geochemistry of the rare-earth elements and uranium in the acidic Berkeley Pit lake, Butte, Montana. Chem. Geol. 2003, 198, 269-288. [CrossRef]

93. Ayora, C.; Macías, F.; Torres, E.; Lozano, A.; Carrero, S.; Nieto, J.M.; Perez-Lopez, R.; Fernandez-Martínez, A.; Castillo-Michel, H. Recovery of Rare Earth Elements and Yttrium from Passive Remediation Systems of Acid Mine Drainage. Environ. Sci. Technol. 2016, 50, 8255-8262. [CrossRef]

94. Olias, M.; Ceron, J.C.; Fernández, I.; De la Rosa, J. Distribution of rare earth elements in an alluvial aquifer affected by acid mine drainage: The Guadiamar aquifer (SW Spain). Environ. Pollut. 2005, 135, 53-64. [CrossRef] [PubMed]

95. Elderfield, H.; Upstill-Goddard, R.; Sholkovitz, E.R. The Rare Earth Elements in Rivers, Estuaries, and Coastal Seas and Their Significance to the Composition of Ocean Water. Geochim. Cosmochim. Acta 1990, 54, 971-991. [CrossRef]

96. Protano, G.; Riccobono, F. High contents of rare earth elements (REEs) in stream waters of a Cu-Pb-Zn mining area. Environ. Pollut. 2002, 117, 499-514. [CrossRef]

97. Prudêncio, M.I.; Valente, T.; Marques, R.; Sequeira Braga, M.A.; Pamplona, J. Geochemistry of rare earth elements in a passive treatment system built for acid mine drainage remediation. Chemosphere 2015, 138, 691-700. [CrossRef]

98. Prudêncio, M.I.; Valente, T.; Marques, R.; Sequeira Braga, M.A.; Pamplona, J. Rare earth elements, iron and manganese in ochre-precipitates and wetland soils of a passive treatment system for acid mine drainage. Procedia Earth Planet. Sci. 2017, 17, 932-935. [CrossRef]

99. Al-Thyabat, S.; Zhang, P. Extraction of rare earth elements from upgraded phosphate flotation tailings. Miner. Metall. Process. 2016, 33, 23-30. [CrossRef]

100. Chen, M.; Graedel, T.E. The potential for mining trace elements from phosphate rock. J. Clean. Prod. 2015, 91, 337-346. [CrossRef]

101. El-Didamony, H.; Gado, H.S.; Awwad, N.S.; Fawzy, M.M.; Attallah, M.F. Treatment of phosphogypsum waste produced from phosphate ore processing. J. Hazard. Mater. 2013, 244-245, 596-602. [CrossRef]

102. Cánovas, C.R.; Chapron, S.; Arrachart, G.; Rostaing, S.P. Leaching of rare earth elements (REEs) and impurities from phosphogypsum: A preliminary insight for further recovery of critical raw materials. J. Clean. Prod. 2021, 219, 225-235. [CrossRef]

103. El Zrelli, R.; Baliteau, J.Y.; Yacoubi, L.; Castet, S.; Grégoire, M.; Fabre, S.; Sarazin, V.; Daconceicao, L.; Courjault-Radé, P.; Rabaoui, L.J. Rare earth elements characterization associated to the phosphate fertilizer plants of Gabes (Tunisia, Central Mediterranean Sea): Geochemical properties and behavior, related economic losses, and potential hazards. Sci. Total Environ. 2021, 791, 148268. [CrossRef] [PubMed]

104. Yang, X.; Wang, S.; Hu, B.; Zhang, K.; He, Y. Estimation of concentration polarization in a fluidized bed reactor with Pd-based membranes via CFD approach. J. Membr. Sci. 2019, 581, 262-269. [CrossRef]

105. Walawalkar, M.; Connie, K.N.; Gisele, A. Process investigation of the acid leaching of rare earth elements from phosphogypsum using $\mathrm{HCl}, \mathrm{HNO}_{3}$, and $\mathrm{H}_{2} \mathrm{SO}_{4}$. Hydrometallurgy 2016, 166, 195-204. [CrossRef]

106. Hakkou, R.; Benzaazoua, M.; Bussière, B. Valorization of Phosphate Waste Rocks and Sludge from the Moroccan Phosphate Mines: Challenges and Perspectives. Procedia Eng. 2016, 138, 110-118. [CrossRef]

107. Tunsu, C.; Menard, Y.; Eriksen, D.O.; Ekberg, C.; Petranikova, M. Recovery of critical materials from mine tailings: A comparative study of the solvent extraction of rare earths using acidic, solvating and mixed extractant systems. J. Clean. Prod. 2019, 218, 425-437. [CrossRef]

108. Liang, H.; Zhang, P.; Jin, Z.; DePaoli, D.W. Rare Earth and Phosphorus Leaching from a Flotation Tailings of Florida Phosphate Rock. Minerals 2018, 8, 416. [CrossRef]

109. Ettoumi, M.; Jouini, M.; Neculita, C.M.; Bouhlela, S.; Coudert, L.; Taha, Y.; Benzaazoua, M. Characterization of phosphate processing sludge from Tunisian mining basin and its potential valorization in fired bricks making. J. Clean. Prod. 2021, 284, 124750. [CrossRef]

110. Al-Thyabat, S.; Zhang, P. In-line extraction of REE from Dihydrate (DH) and HemiDihydrate (HDH) wet processes. Hydrometallurgy 2015, 153, 30-37. [CrossRef]

111. Hammache, Z.; Berbar, Y.; Bensaadi, S.; Trari, M.; Amara, M. Recovery of light rare earth elements by leaching and extraction from phosphate mining waste (Fluorapatite and Carbonate-Fluorapatite). J. Afr. Earth Sci. 2020, 171, 103937. [CrossRef]

112. Eskanlou, A.; Huang, Q. Phosphatic waste clay: Origin, composition, physicochemical properties, challenges, values and possible remedies-A review. Miner. Eng. 2021, 162, 106745. [CrossRef]

113. He, J.; Kappler, A. Recovery of precious metals from waste streams. Microb. Biotechnol. 2017, 10, 1194-1198. [CrossRef] 
114. Zhang, P. Comprehensive Recovery and Sustainable Development of Phosphate Resources. Procedia Eng. 2014, 83, 37-51. [CrossRef]

115. Pell, R.S.; Wall, F.; Yan, X.; Bailey, G. Applying and advancing the economic resource scarcity potential (ESP) method for rare earth elements. Resour. Policy 2019, 62, 472-481. [CrossRef]

116. Habib, K.; Hansdóttir, S.T.; Habib, H. Critical metals for electromobility: Global demand scenarios for passenger vehicles, 2015-2050. Resour. Conserv. Recycl. 2020, 154, 104603. [CrossRef]

117. Li, X.Y.; Ge, J.P.; Chen, W.Q.; Wang, P. Scenarios of rare earth elements demand driven by automotive electrification in China: 2018-2030. Resour. Conserv. Recycl. 2019, 145, 322-331. [CrossRef]

118. Evans, K. The history, challenges, and new developments in the management and use of bauxite residue. J. Sustain. Metall. 2016, 2, 316-331. [CrossRef]

119. Dai, S.; Seredin, V.V.; Ward, C.R.; Jiang, J.; Hower, J.C.; Song, X.; Jiang, Y.; Wang, X.; Gornostaeva, T.; Li, X.; et al. Composition and modes of occurrence of minerals and elements in coal combustion products derived from high Ge coals. Int. J. Coal Geol. 2014, 121, 79-97. [CrossRef]

120. Qi, H.; Rouxel, O.; Hu, R.; Bi, X.; Wen, H. Germanium isotopic systematics in Gerich coal from the Lincang Ge deposit, Yunnan, Southwestern China. Chem. Geol. 2011, 286, 252-265. 